\section{DIMENSIÓN ESPACIAL DE LA MOVILIDAD COTIDIANA UNIVERSITARIA: EL CASO DEL GRAN VALPARAÍSO ${ }^{1}$}

Luis Álvarez A. ${ }^{2}$

Lisandro Silva A. ${ }^{3}$

Marcela Soto C. ${ }^{4}$

\section{Resumen}

Este trabajo obedece a la necesidad de conocer los patrones de movilidad cotidiana universitaria desde los lugares de residencia hacia el campus universitario y como estos han ido cambiando debido a la creciente influencia en las dinámicas de cambio del contexto urbano metropolitano del Gran Valparaíso.

Estas dinámicas de cambios se caracterizan por desequilibrios funcionales al interior de la estructura metropolitana, y a un incremento sustantivo en la accesibilidad global producto de programas de inversión en infraestructura vial en sus principales corredores de transporte, llevando a desarrollos urbanos desiguales y crecientes.

\section{SPATIAL DIMENSION OF UNIVERSITY STUDENTS' DAILY COMMUTING: GREATER VALPARAISO CASE STUDY ${ }^{1}$}

\author{
Luis Álvarez A. ${ }^{2}$ \\ Lisandro Silva A. ${ }^{3}$ \\ Marcela Soto C. $^{4}$
}

\section{Abstract}

This research explores the need to identify the every day university students commuting patterns from their place of residence to the university and how this have been changing due to new dynamic influences within the urban metropolitan context of Gran Valparaiso, Chile.

These dynamic urban changes are mainly characterized by functional imbalances within the metropolitan urban structure, and a substantial increase in global accessibility to road infrastructure investment programs on its main urban corridors producing an uneven and increasing urban development. These changes 
Estos cambios vistos desde una comunidad móvil específica como es el habitante universitario, nos permite visualizar nuevas tendencias de movilidad, asociadas a un modelo más centrífugo que "externaliza" crecientemente la residencia de los alumnos hacia el contexto urbano metropolitano, cuyas consecuencias sociales y urbano-ambientales pretende develar la investigación.

\section{PALABRAS CLAVES: MOVILIDAD SUSTENTABLE, DESARROLLO URBANO METROPOLITANO, PATRONES DE LOCALIZACIÓN RESIDENCIAL.}

Fecha de Recepción: 28.11.08

Fecha de Aceptación: 23.03.09

1 Este artículo preliminar es el resultado de una investigación que se desarrolla en el marco del Concurso de Fondos de Investigación 2008, de la Dirección General de Investigación y Postgrado de la Universidad Técnica Federico Santa María, en la Línea de Territorio y Gestión del Departamento de Arquitectura.

2 Chileno, Geografo, Magíster en Urbanismo Universidad de Chile, Profesor Departamento de Arquitectura UTFSM, Profesor Geografía Pontificia Universidad Católica de Valparaíso, Especialista en Sensores Remotos, SIG, Análisis Espacial, correo electrónico: luis. alvarez@usm.cl.

3 Chileno, Arquitecto (1983) y Magíster en Urbanismo (1995) Universidad de Chile, Profesor de Urbanismo en pregrado en FAU, U. de Chile y Universidad Andrés Bello,y de Postgrado en Universidad de Viña del Mar e INVI, de Chile, correo electrónico: lisandro.silva@usm.cl.

4 Chilena, Ms. Arquitecta, Profesora Universidad Técnica Federico Santa María, Coordinadora Línea Territorio y gestión UTFSM, Investigadora de doctorado de la Technische Universiteit Delft, correo electrónico: marcela.soto@usm.cl. studied from a specific mobile group as university students are, allowed this study to visualize new mobility trends, linked to a more centrifugal model that "externalizes" the students' residents to a metropolitan urban context, with social and urban-environmental consequences that this investigation is trying to explore.

\section{KEYWORDS: SUSTAINABLE MOBILITY, METROPOLITAN URBAN DEVELOPMENT, RESIDENTIAL PATTERS.}

\author{
Received: 28.11 .08
}

Accepted: 23.03 .09

1 This preliminary article is the result of an on going investigation within the framework of Concurso de Fondos de Investigación 2008, de la Dirección General de Investigacióny Postgrado de la Universidad Técnica Federico Santa María, en la Línea de Territorio y Gestión del Departamento de Arquitectura (Universidad Tecnica Federico Santa Maria grant).

2 Chilean, Geographer, Master's in Town-planning Universidad de Chile, professor in Departamento de Arquitectura UTFSM (Architecture Department), Geography professor in Pontificia Universidad Católica de Valparaíso, specialist in Remote Sensors, GIS, Spatial Anaylisis, Email: luis.alvarez@usm.cl.

3 Chilean, Architect (1983) and Master's in Town-planning (1995) U. de Chile, Urban-planning professor in under-graduated courses in FAU, U. de Chile y Universidad Andrés Bello and post graduated courses in Univesidad de Viña del Mar and INVI Universidad de Chile, Email: lisandro.silva@usm.cl.

4 Chilean, Ms. Architect, Universidad Técnica Federico Santa María professor, Territory and Managment Line Coordinator UTFSM, PhD. Researcher of the Technische Universiteit Delft, Email: marcela. soto@usm.cl. 


\section{INTRODUCCIÓN}

La concentración de población y ciertas actividades de servicios en grandes zonas metropolitanas está ocurriendo en todos los países industrializados y urbanizados. En este contexto la condición dominante para tener acceso al mercado de trabajo, comodidad, educación y ocio, es la movilidad. El objetivo central de la investigación realizada por académicos investigadores de la Línea de Territorio y Gestión del Departamento de Arquitectura, financiado por el CONCURSO DE FONDOS DE INVESTIGACIÓN 2008, de la Dirección General de Investigación y Postgrado de la Universidad Técnica Federico Santa María, es poder realizar un análisis de tendencia sobre la movilidad de los estudiantes de la Universidad desde sus lugares de residencia hasta la Casa Central en el Gran Valparaíso. Siendo este tema de vital importancia ya que lo viajes universitarios concentran casi el $50 \%$ de los viajes de un total de 1.263.663 que se realizan diariamente en el Gran Valparaíso, según la última encuesta Origen Destino de la SECTRA V Región.

El contexto a estudiar son áreas metropolitanas como unidades nacidas a partir de una conurbación, por tanto reúnen complejidad de gran ciudad, donde la movilidad es la principal manifestación. El Gran Valparaíso, como sistema de estudio, es un área metropolitana conformada por 5 comunas con

\section{INTRODUCTION}

Concentration of population and certain services activities is happening in big metropolitan zones in every urbanized and industrialized country; within this context the main condition to have access to labor market, comfort, education and leisure is mobility. The main objective of this study done by academic researchers of the line of Territory and Management of the Department of Architecture, financed by CONCURSO DE FONDOS DE INVESTIGACION 2008 (University grant) from the Universidad Santa Maria Direccion General de Investigacion (Research General Department), is to analyze the students' mobility tendency from their residences to the University main Campus in Gran Valparaiso. It is a vital variable to study as the students concentrate almost 50\% of the total 1,263,663 daily travels according to the latest (Origin Destination) survey done by SECTRA V Region.

The study will focus in metropolitan areas emerged out of conurbation which implies big city complexities where commuting is one its main manifestation. Gran Valparaiso, as case study includes a metropolitan area of 5 communities with a population of 850,000 
una población de alrededor de 850.000 habitantes. En rigor en este sistema el recambio productivo, el desplazamiento de la hegemonía de los servicios, flexibilidad laboral, oportunidades educacionales y diversidad de la misma, obligan a tratar el tema como un problema de carácter topológico, por tanto territorial; en rigor la población dentro del Gran Valparaíso se desplaza un $27 \%$ más de lo que lo hizo en los últimos 15 años, y un grupo sustantivo de población que se desplaza son los estudiantes. Según Marcial Echenique (urbanista a cargo de todos los grandes proyectos infraestructura de transporte de los 10 últimos años) la movilidad ha aumentado en un $250 \%$ a partir de la puesta en marcha de las grandes concesiones en Chile, en particular el Gran Valparaíso, que cuenta con una de las concesiones nacionales más grandes como lo es el "Troncal Sur", además se agregan proyectos de gran envergadura, públicos, como la cuarta etapa de la Avenida España, el Acceso Sur al puerto de Valparaíso y la reposición del Camino Internacional, entre otras.

La movilidad urbana de las personas, afecta la productividad y la calidad de vida de las personas, lo cual se transfiere al ámbito de los estudiantes universitarios, bajo formas de crecientes tiempos de viajes a la universidad, contaminación atmosférica, menor tiempo de ocio (para actividades extracurriculares), menor tiempo dedicado al estudio en casa, y bajas de rendimiento por agotamiento en viajes más largos e incómodos, inhabitants; taking in consideration the productive replacement system, services hegemony displacement, labor flexibility, educational opportunities and its diversity makes a must to treat it as a topological problem, in otherwords, territorial. In fact Gran Valparaiso population moves $27 \%$ more than in the last 15 years, and a substantial number of floating population are students. According to Marcial Echenique (urban planner in charge of all the big transport infrastructure projects the last 10 years) mobility has increased in $250 \%$ since big concessions started in Chile, particularly in Gran Valparaiso that has two of the major national concessions as it is "Troncal Sur" as well as large public projects as the fourth section of Avenida España, South access to Valparaiso port and the international road rebuilding among others.

People's urban mobility affects productivity and their quality of life which influences university students'world, increasing their commuting time to the university, atmosphere contamination, less leisure time (extra curricular activities), less time studying at home, low productivity and exhaustion due to longer and more uncomfortable commuting and increasing levels of acoustic and atmospheric contamination. According to MINEDUC (Education Ministry) 
y crecientes niveles de contaminación acústica y atmosférica. Según datos de la División de educación superior del MINEDUC, el porcentaje de la población joven entre los 18 y 24 años matriculados en pregrado de las universidades, ha aumentado de un $16,3 \%$ en 1992 , a un $33,3 \%$ en 2005 , con un crecimiento anual promedio de $1,3 \%$. Este segmento de jóvenes que han ingresado al sistema universitario, prácticamente se ha duplicado en una década.

La Universidad Santa María con sus 7.800 alumnos, aporta con aproximadamente el 11\% de la matrícula universitaria regional, y con su emplazamiento en la Avenida España, principal eje conector intercomunal entre Valparaíso y Viña del Mar y el resto del sistema urbano (Con Con, Quilpué y Villa Alemana), a los pies del Cerro Los Placeres, marca los patrones de movilidad diaria del conjunto urbano, en la medida que sus alumnos comienzan a desplegar sus residencias en el espacio urbano metropolitano, cada vez más alejados de su entorno inmediato en la medida que las mejoras en las condiciones de accesibilidad lo permiten.

Por otro lado, la política fundacional de la Universidad en cuanto a integrar "puertas adentro" toda la oferta universitaria incluyendo la residencia al interior del campus universitario, ha cambiado a lo largo del tiempo en la medida que la realidad del país fue cambiando y las características
Higher Education Division data, the young population percentage, between 18 and 24 years old enrolled in pre-graduated studies in the university has increased from $16.3 \%$ in 1992 to $33.3 \%$ in 2005 with an average annual growth of $1.3 \%$. The young population segment that has enrolled in the university has almost doubled in the last decade.

Santa Maria University with its 7,800 students, adds more less $11 \%$ of the regional university enrollment and it moves mainly through Avenue España, the main connecting axis between the cities of Valparaiso and Viña del Mar and the rest of the urban system (Con Con, Quilpue and Villa Alemana) at the edge of Los Placeres Hill that set the daily mobility patterns within the urban area, as the students move their residences within the metropolitan urban space, even further away from the immediate university area surroundings as accessibility to those areas improves.

On the other hand, the university founding policy to integrate "puerta adentro" (inside door) all the university, including in-campus university residence has changed through out time as the country's reality has and the students socio-economic characteristics have too. 
socioeconómicas y regiones de origen de los alumnos también.

La red de ayuda social de la Universidad para sus alumnos, así concebida, y su permanencia hasta hoy, han generado un nivel de dependencia entre el Campus de la Universidad y el contexto urbano inmediato creciente, en la medida que la Residencia de los alumnos, originalmente al interior de los recintos universitarios (en la modalidad de Pensionado Universitario), fue trasladando el hospedaje a la ciudad y en primera instancia en pensiones en el barrio aledaño del Cerro Placeres.

El vínculo de asistencia social se mantiene y por tanto comienza a desarrollarse un emplazamiento de cercanías basado en la interacción residenciauniversidad mediada por la oferta urbana del Gran Valparaíso, en cuanto a servicios urbanosresidenciales y corredores de transporte que demandan alumnos y profesores. Finalmente las relaciones entre contexto de oferta urbana metropolitana en la cual se emplaza la universidad con los patrones de desplazamiento de los alumnos según estrato socioeconómico, logran configurar un territorio claramente distinguible y caracterizable.
The university students welfare network that was conceived this way and has lasted up to now, has generated a dependency between the University Campus and the immediate growing urban context as the students' residence have changed, originally within the university campus (university boarding houses modality) that was transferred to city residence, at the beginning in the adjoining Los Placeres hill neighborhood guest houses.

The social welfare linked has been kept, hence location proximity development has emerged based in residence-university interaction measured by Gran Valparaiso real estate offer related to its urban-residential services and transport corridors needed by the university students and staff. Finally, the relationship between the metropolitan urban, real estate offers and where the university is located in relation with the students' mobility patterns linked to their socio-economic origin which allows to clearly identified and characterize it. 
MARCO DE REFERENCIA

\section{EL PROBLEMA DEL MODELO DE MOVILIDAD URBANA}

Al principio del siglo XXI podemos convenir que si la demanda del transporte continúa creciendo a la misma velocidad que la economía y si se asume que el transporte terrestre como aéreo contribuyen sobre todo a la contaminación ambiental y a la injusta accesibilidad a los servicios y a los medios públicos de la ciudad, las metas de movilidad sostenible van lejos detrás. Si admitimos que el sistema de la movilidad es hoy en día principalmente integrado por personas, información y productos y que su técnica para llevar o almacenar es totalmente interdependiente, la presión de estar "just in time" por las reglas de la economía es análoga con el transporte urbano, que exige hoy en día, un servicio rápido, digno de confianza y recomendable a otros. Si esto lo llevamos a los sistemas económicos modernos, nos encontramos con mayores exigencias, caracterizadas por la intensificación de las presiones para disminuir los costes por medio del aumento de la productividad y de la reducción de las deficiencias, inducen la atención a las redes necesarias por el sistema de transporte para suministrar de una mejor manera el proceso de producción.

Todos los países reconocen hoy en día la función fundamental que realiza el transporte en el

\section{REFERENCE FRAMEWORK}

\author{
URBAN COMMUTING MODEL PROBLEM
}

It can be said that if transport demand increases at the same speed as the economy does in the $21^{\text {st }}$ century, and if it is assumed that either land or air transport mainly contribute to environment pollution; also the uneven city's public services and means access; the sustainability goals are far behind it. If it is agreed that today's commuting system is made of: people, information and products and that its technology to store or carry it out is completely interdependent, pressuring to be just on time for economic reasons analogous to urban transport that demands a fast service, reliable and good to be recommended to others. If we make the analogy to modern economic systems, it is more demanding and is characterized by more pressure for lower cost trough increasing productivity and reducing deficiencies that leads put attention to the necessary transport system networks to provide in a better way the production process.

Every country recognizes nowadays the transport system as a key factor for 
desarrollo económico y se sienten forzados a satisfacer la proliferación de infraestructuras viales por las demandas de movilidad debido a las presiones impuestas por la reestructuración de la globalización. El mercado competitivo entre las ciudades, los países y las regiones se integra cada vez más en un sistema mundial, una mayor conexión entre los recursos y los mercados por medio de cadenas mundiales de provisiones. Se continúa levantando los niveles de comercio internacional y las relaciones recíprocas económicas, por esa razón las alianzas de producción, y externalización de recursos está dada por países que ofrecen ventajas competitivas. La demanda de redes extensas de transporte por estos sistema mundiales de mercados siguen sosteniendo la ecuación asociativa entre el crecimiento económico y el del transporte.

En este contexto del neo-liberalismo debemos tratar algunos aspectos importantes que ayuden a entender los efectos directos de la globalización en el aumento de la movilidad. La liberalización del mercado de transporte al sector privado sigue teniendo una doble ecuación; un sector muy intensivo en inversión privada pero con fuerte servicio de interés público. De esta manera, aunque la desregulación utiliza la competición eso debiera animar las transformaciones a nivel de organización del sector privado del transporte y con ello un aumento en las innovaciones tecnológicas; esta aparente eficacia ha sido en parte economic development and they feel compel to satisfy road infrastructure required by the population mobility imposed by globalization restructuring. The competitive market among cities and countries and regions, that each day, integrates even more, a world system with major resources and markets connection through world chains of supplies. The international trade and reciprocal economic relations level increases leading to production alliances and resources externalization given by countries that offer competitive advantages. The external transport networks demands made by this world markets system still support the associative equation between economic growth and transport.

Within this context of neo-liberalism, some important aspects have to be considered to help understand the direct effect of globalization on mobility. The transport market liberalization to the private sector still has a double equation, on one hand a large private investment though a service of high public interest. This way, although de-regularization uses competition and this should encourage transformations in an organizational level of the private transport sector and with it, increasing technological innovations; still this has not been completely 
pero no completamente acertada. Absolutamente perceptible, la desregulación de los mercados de transporte ha tendido más a ser de apoyo de oligopolios que a la competición verdadera y los efectos directos de este modelo llevan a una mala calidad del servicio o a compromisos no serios del sector privado en vista de la internalización del coste externo del transporte. Finalmente todas las externalidades negativas de transporte en zonas urbanas son asumidas por el ciudadano o el gobierno central.

\section{MOVILIDAD SOSTENIBLE}

El planeamiento urbano y la organización de las ciudades influencian de manera directa las pautas y las características de la movilidad, y las políticas de transporte. Los distintos medios de transporte mecánico, la proporción de peatones o la reintroducción de la bicicleta, son los elementos que derivan directo del planeamiento de ciudad. Si bien algunas políticas urbanas dan prioridad a los medios de transporte públicos, otras intentan balancear transporte motorizado de no motorizado y otras, promueven el transporte privado y la construcción de infraestructuras viales de grandes dimensiones. Todas estas opciones requieren un diseño y un planeamiento conveniente a cada modelo de la movilidad. Sin embargo, esta relación es recíproca, puesto que cada modelo de movilidad accurate in practice. It has been absolutely clear the transport markets de-regularization has been more support to oligopolies than real competition and the direct effect of this model has been a very bad quality service or lack of serious commitment from the private sector due to the internalization of external cost of transport. Finally, all the negative transport externalities in urban areas are taken over by the citizens and central government.

\section{SUSTAINABLE MOBILITY}

Urban town planning and cities organization directly influences mobility characteristics and guidelines as well as transport policies. The different mechanical means of transport, pedestrians proportion or bicycle use reinsertion is directly derive from the city town planning. Even though some urban policies give priority to means of public transport, others try to balance motor transport from non-motor one and others, promote private transport and large roads infrastructure construction. All this options required design and planning according to the needs of each mobility model, however, this is a reciprocal relationship, as each mobility 
requiere un modelo más eficiente y más sostenible de ciudad ${ }^{5}$.

El resultado de más de dos décadas de reflexión sobre la extensión de las ciudades ha dado lugar a la elaboración de un nuevo concepto de desarrollo; la sustentabilidad, que marca los criterios de cualquier actividad humana que implique el uso de recursos naturales y humanos. En este grupo de actividades y de estrategias, el transporte y la movilidad deben desempeñar un rol determinante. En la conferencia de las Naciones Unidas en Río (1992) existen términos específicos que sintetizan las características que el sector de transporte tendría que adoptar para considerar una actividad que se puede enmarcar en la sustentabilidad. Si bien la mayor parte de las investigaciones sobre transporte o movilidad se focalizan en las emisiones, ruido y gastos energéticos, que resultan en avances tecnológicos, también implica transformaciones en la organización de espacio y de tiempo. El problema no es ir más rápidamente, sino disfrutar de una mayor viabilidad ${ }^{6}$ para alcanzar la destinación final de una manera agradable. Es necesario estimular distancias cortas y tomar diversos medios de transportes que permitan una velocidad más baja como las bicicletas o aun caminar, con el propósito de la recuperación de una mejor calidad de vida. Además se busca eficiencia

5 MIRALLES-GUASH, 2002, pág.41-42.

6 El concepto de viabilidad tiene que ver con las condiciones que posee la calle 0 camino que usas para viajar. (MIRALLES-GUASH, 2002, pág.27-44). model requires a more efficient and sustainable city model ${ }^{5}$.

The result of over two decades analyzing the cities extension has ended in the elaboration of a new development concept that gives the criterion of any human activity that implies natural and human resources usage. Within this group of strategies and activities, transport and mobility should have a key role. In the U.N. Conference in Rio (1992) specific terms were mentioned that summarize the characteristic the transport sector should have to be able to be a sustainable activity. Even if most researches in transport or mobility focus in contamination emissions, noise and energy expending that leads to technological advances, it also implies transformations in space and time organization. The problem is not to go faster, but to access to a better viability ${ }^{6}$ to reach its final destination in a pleasant way. It is necessary to motivate short distances and diverse means of transport that allow a lower speed as a bicycle or even walks, aiming to improve the quality of life. It is also targets to reduce mobility, to have the services needed near the residence place and

5 MIRALLES-GUASH, 2002, pages.41-42

6 The viability concept is related to the conditions that the street or road use to travel has. (MIRALLES-GUASH, 2002, pág.27-44 
en reducción de movilidades, tener servicios cerca del lugar de residencia, con ello generar nuevas centralidades, consolidar zonas urbanas, dotar de equipamiento y servicios y por supuesto con ello fortalecer comunidades, siendo esto último el propósito de la investigación.

\section{CONTEXTOO METROPOLITANO DE ACCIÓN}

Finalmente se analizan las dinámicas metropolitanas como contexto de acción de los patrones de localización residencial universitaria en el caso de los alumnos de la Casa Central de la Universidad Santa María. Actualmente es un hecho ampliamente investigado que el crecimiento de las ciudades está relacionado con la capacidad de éstas para movilizar y almacenar personas, información y bienes, en lo que autores como Ascher, denominan "modelo de movilidad PIG"7. Las políticas urbanas, como contraparte, se orientan a adaptar las ciudades a la velocidad de desplazamiento y la baja densidad habitacional. Estas líneas de acción pública, tienen efectos agregados en la creciente falta de equidad social en el acceso a los bienes y servicios urbanos, que sumados con los efectos de las políticas de movilidad urbana, acrecientan los procesos de

7 ASCHER Francois, 2004, pág. 352-353. to generate new centers within it, consolidate urban areas, provide with services and to equip and of course strengthen the communities. This is the major purpose of this investigation.

\section{METROPOLITAN CONTEXT OF ACTION}

Finally the metropolitan dynamics are analyzed within the context of the university students' residential location patterns of the main Santa Maria University campus students. Cities' growth is largely investigate in recent years related to its capacity to move and hold people, information and goods in what authors like Ascher call "PIG mobility model" ${ }^{7}$. On the other hand, urban policies are oriented to adapt cities to mobility speed and low housing density. This line of public action has added effects in its growing lack of social equity related to urban goods and services access, and if it is also taken in consideration the urban mobility policies effects that increase the urban concentration process or metropolization with

7 ASCHER Francois, 2004, pages. 352-353. 
concentración urbana o metropolización, en procesos de doble causalidad, bajo procesos de polarización espacial y efectos de dispersión urbana en todas las escalas del territorio ${ }^{8}$.

Desde esta perspectiva, es que los estudios parciales de movilidad están ligados a procesos metropolitanos de dinámicas urbanas que justifican, para el presente estudio, explorar el contexto metropolitano del Gran Valparaíso como marco explicativo de fenómenos emergentes del estudio específico de la movilidad de los alumnos de la Universidad Santa María, por dos razones específicas:

a) Por un lado, la estructura de movilidad cotidiana del Gran Valparaíso (en términos de viajes pendulares diarios entre el hogar y el trabajo y los centros de servicios), muestra una estructura monocéntrica basada en el plan de Valparaíso, como principal centro atractor de viajes por motivos de estudio, servicios y trabajo en los diferentes períodos del día.

b) La Región de Valparaíso es la segunda centralidad en matrículas universitarias del país y del total de viajes diarios en el Gran Valparaíso, los que se realizan por motivo de estudios constituyen el $28,4 \%$, siguiendo en importancia a los viajes al trabajo que constituyen el 40,6\% de los viajes

8 ASCHER Francois, 2004, pág. 358-359. a low spatial polarization process and urban dispersion effects in all the territorial scales ${ }^{8}$.

From the perspective that partial mobility studies are linked to metropolitan processes of urban dynamics that justify for this study, to explore the metropolitan context of Gran Valparaiso as a framework to explain the study of this emerging phenomena, specifically in this investigation University Santa Maria students' mobility for two specific reasons:

a) On one hand, the daily mobility structure of Gran Valparaiso (in terms of back and forth daily travel from home and work and services centers). It shows a mono-centric structure underneath Valparaiso's town planning as the main reason to travel, motivation such as access to study, services and work during different times of the day.

b) Valparaiso Region is the second concentration of university enrollment in the country and out of the total mobility of Gran Valparaiso, the ones done by motives like studying are $28.4 \%$ following in importance work travels that are $40.6 \%$ of the daily travels. Both motivation are $69 \%$ of them.

8 ASCHER Francois, 2004, pages. 358-359. 
diarios. Ambos motivos concentran el 69\% de los viajes.

Por lo tanto, es atendible que los patrones de desplazamientos de los alumnos de una de las universidades más importantes de Valparaíso, localizada en torno de sus principales centros atractores de viajes metropolitanos diarios, se vean influenciados por la oferta urbana de servicios urbanos y de transporte. De hecho la oferta residencial obedece a dos segmentos complementarios de demanda por residencia durante el año, como son las pernoctaciones turísticas (en los meses de enero-febrero) y las residencias para estudiantes universitarios durante el período marzo-diciembre. Si la sustentabilidad ambiental de las ciudades depende de sus modelos de movilidad, las localizaciones universitarias en el Gran Valparaíso, como atractores del segundo motivo de viajes diarios al estudio, justifica la preocupación respecto de dichos segmentos de demanda de transporte relacionados con la base económica del conjunto urbano metropolitano en crecimiento.

\section{EL GRAN VALPARAÍSO COMO ESTRUCTURA URBANA EN TRANSICIÓN}

La transición de una conurbación a un área metropolitana, es un proceso natural en el metabolismo de las áreas urbanas de cercanías,
For this reason, it is relevant the mobility patterns of one of the most important university in Valparaiso, located in the center of the city's metropolitan daily travel points which are influenced by urban services and transport. In fact real state residential offer comes from two different complementary origins; one the regular residential demand, all year round and other university students housing needs during the school year (March-December) and the tourist accommodation during the summer (January and February). If the cities' environmental sustainability depends in its mobility model, the Universities location in Gran Valparaiso, and if the university students are the second largest group of people that commutes within the metropolitan area, it does make sense to be concerned about this group transport demands related to the economic variable within the metropolitan urban growing set.

\section{GRAN VALPARAISO AS A URBAN STRUCTURE IN TRANSITION}

The transition from a conubanization to a metropolitan area is a natural process in the neighboring urban areas metabolism, a 
un proceso de transición que aglutina, desarrolla interacción y complejiza las relaciones.

Valparaíso y su contexto desarrollado durante el siglo XX, organizó, reforzó y estructuró una unidad denominada Gran Valparaíso, que alcanza hoy la cantidad de 822.829 habitantes; si bien hoy administrativamente exige hablar de ciudades de Valparaíso, Viña del Mar, Quilpué, Villa Alemana y Concón, todas ellas estructuran una unidad metropolitana, bastante integrada y organizada, habiéndose organizado como suburbios, para pasar a una conurbación, este último concepto de Patrick Geddes $^{9}$, este concepto permitió entender las primeras relaciones entre las estructuras urbanas conurbadas fundamentalmente por los grados de accesibilidad generados a partir de las funciones y especialidades territoriales, estas relaciones terminan organizando y relacionado las dinámicas urbanas a modo de sistemas abiertos al contexto en el cual se desarrollan; el resultado es un "Área Metropolitana".

\section{ÁREA METROPOLITANA DE VALPARAÍSO, ORGANIZACIÓN E INTERACCIÓN}

El sistema urbano metropolitano del Gran Valparaíso tiene su origen en el desarrollo portuario de la ciudad de Valparaíso; este origen obliga al desarrollo infraestructural ferroviario de

$9 \quad$ HALL Peter (2000). Pag. 23. transition process that agglutinates, develops interaction and more complex relationships.

Valparaiso and its particular context was developed during the 20th Century, organized, reinforced and structured a unit named Gran Valparaiso that has 822,829 inhabitants, although now for administrative reasons must be referred as Valparaiso, Viña del Mar, Villa Alemana, Quilpue, Con Con, all of them together are a metropolitan unit, quite integrated and organized as suburbs at first to then become a conurbanization, Patrick Geddes'9 concept. This concept allows understanding the first conurban structures relationships, mainly through the accessibility degrees generated from the functions and territorial specialties. This relationships end up organizing and relating urban dynamics as an open system mode in the context where they develop, becoming a "Metropolitan Area".

\section{VALPARAISO METROPOLITAN AREA, ORGANIZATION AND INTERACTION.}

Gran Valparaiso metropolitan urban system started developing as a port city which demanded railroad infrastructure developing on the terraces and costal plains of the Marga

$9 \quad$ HALL Peter (2000). Page. 23. 
las terrazas y planicies costeras de la cuenca del Margamarga, situación que genera las ciudades del interior (Viña del Mar, Quilpué y Villa Alemana); esto se refuerza por las acciones territoriales de la revolución industrial, preferentemente por el "Desarrollo Industrial Temprano" afincado en el anexo industrial de Viña del Mar.

La estructura urbana de Valparaíso tiene la siguiente configuración demográfica:
Margabasin, generated by the neighboring cities of (Viña del Mar, Quilpue and Villa Alemana), that has been reinforced by the industrial revolution territorial actions, particularly by the "Early Industrial Development" established in Viña del Mar's industrial belt.

Valparaiso's urban structure has the following demographic configuration:

TABLA 1. DATOS CENSALES Y PROYECCIÓN ÍNTER CENSAL INE-CHILE, 2005. TABLE 1. CENSUS DATA AND INTER CENSUS PROJECTION INE-CHILE, 2005.

\begin{tabular}{lllllll} 
Comuna & 1990 & 1992 & 1995 & 2000 & 2002 & 2005 \\
Valparaíso & 281,940 & 282,840 & 281,540 & 269,320 & 270,242 & 270,800 \\
\hline Viña del Mar & 283,300 & 285,464 & 290,120 & 295,600 & 298,828 & 301,210 \\
\hline Quilpué & 101,641 & 104,203 & 112,430 & 122,885 & 127,128 & 128,230 \\
\hline Villa Alemana & 69,397 & 71,672 & 78,509 & 87,589 & 95,268 & 96,792
\end{tabular}

Valparaíso lideró el desarrollo de la Conurbación, esta fue fundamentalmente apoyada por el desarrollo infraestructural y una funcionalidad primitiva de orden territorial, a saber:

Viña del Mar, como anexo industrial de Valparaíso, Quilpué como receptáculo de las externalidades industriales de Viña del Mar y Villa Alemana como apoyo ferroviario con las ciudades del Valle del Aconcagua.
Valparaiso led the conubranization development that was mainly supported by the primitive infrastructure and functionalism of the territorial order as follow:

Viña del Mar as Valparaiso's industrial annex, Quilpue as receptacle of Viña de Mar's industrial externalities and Villa Alemana as railroad support with Aconcagua Valley cities. 
El incremento de los equipamientos industriales y un proyecto de desarrollo nacional temprano, ven incrementar las estructuras urbanas del interior, al punto de lograr incrementos sustantivos en la envergadura urbana.

\section{MOVILIDAD METROPOLITANA}

El proyecto de "Desarrollo Nacional" paulatinamente reconfigura el aspecto de la Conurbación de Valparaíso, el recambio de la ciudad de Viña del Mar de un anexo industrial de Valparaíso a un balneario inducido por el Estado, las políticas urbanas de mediados del siglo veinte, transforman las unidades urbanas del interior, fundamentalmente apoyadas en las necesidades de vivienda, primero vinculadas al proceso generado por la industrialización. La oferta de vivienda y equipamiento se hace deslocalizadamente (Quilpué, Belloto), y las actividades económicas permanecen concentradas en Valparaíso, entre ellas las universitarias.

Paulatinamente el incremento de las necesidad de vivienda, la creación del MINVU y sus corporaciones urbanizadoras, hacen de la estructura urbana conurbada una organización que comienza a estructurarse y jerarquizarse territorialmente, ciudad concentradora de la actividad económica y del rol del Estado como Valparaíso, equipamiento de apoyo y equipamiento residencial en Viña del Mar, acción de vivienda social y acometidas espontáneas en Quilpué y Villa Alemana.
The increment of the industrial equipment and a early development project has seen the increase of the inner cities urban structures to the point of large increment of the urban structure.

\section{METROPOLITAN MOBILITY}

The "Desarrollo Nacional" Project has gradually reconfigured the conurbanization aspect of Valparaiso and Viña del Mar's change from a Valparaiso's annexed industrial city to a beach resort pushed by State driven policies. Mid 20 th Century urban policies led to transform the inland urban units, mainly cause at first by housing needs emerged by industrialization. The real estate housing and equipment offer were residential (Quilpue and Belloto), and the economic activities were kept in Valparaiso, including the universities.

Gradually the housing need increased, the MINVU (Ministry of Housing and Urbanism) creation and its urbanization offices makes the urban structure organize and begins to structure, rising a territorial hierarchy; economic activity city center and of State offices representation in Valparaiso, support infrastructure and residential area in Viña del Mar, social housing and spontaneous growing in Quilpue and Villa Alemana. 
Las profundas transformaciones de las políticas urbanas a partir de 1979, el nuevo rol del Estado y la acometida de la acción privada, transforma sustantivamente la condición urbana dando paso a la configuración Metropolitana.

En síntesis las transformaciones se traducen en; Distribución inversamente proporcional a la centralidad histórica, concentración de inversiones en las ciudades con acumulación de ventajas (Accesibilidad, equipamientos, valores de suelo y ausencia de competencias con las actividades periféricas), Viña del Mar supera en cantidad de habitantes a Valparaíso (1984), y la concentración de actividades de servicio de orden privado, generan una situación similar.

La reorganización del Gran Valparaíso, toma carácter multifocal, reorientándose y especializándose de la siguiente forma:

- Valparaíso concentrando la estructura administrativo-estatal, con énfasis en las actividades productivas.

- Viña del Mar, concentración de servicios, vivienda y turismo.

- Quilpué y Villa Alemana, residencial con apoyo de la subsidiaridad del Estado, se constituyen en las ciudades dormitorio del sistema.

- Concón, con una creación reciente, se especializa en el desarrollo especulativo residencial y turístico.
The deep transformation of urban policies since 1979, the new role of the State and the private sector investment reshaped the urban conditions changing it into a Metropolitan configuration.

Inshorttransformationtranslatedinto:Inversely proportional distribution to the historical centrality, investment concentration in cities with accumulative advantages (accessibility, infrastructure, salaries' value, and lack of competition in peripheric activities). Viña del Mar has more inhabitants than Valparaiso (1984) and the private sector services concentration shows a similar situation.

Gran Valparaiso reorganization has a multifocal approach, re-orienting and specializing in the following way:

- Valparaiso concentrates the State administrative structure, emphasizing productive activities.

- Viña del Mar concentrates services, housing and tourism.

- Quilpue and Villa Alemana are mainly residential with State housing subsidiary programs which make them, the system dormitory cities.

- Con Con as a newly developed city, specializes in speculative residential and tourist city 
La organización metropolitana genera unidades desarrolladas por extensión que obligan a desplazamientos obligados dentro del contexto metropolitano toda vez que las transformaciones generadas por la globalización construyen un nuevo contexto, más flexible e incierto.

Las características del área metropolitana se resumen en:

- Flexibilidadlaboral,queobligaaldesplazamiento permanente.

- Segregación; estructura urbana fractalizada de acuerdo a la distribución socioeconómica.

- Infraestructurada; grandes infraestructuras viales y ferroviarias generadoras de territorios de cercanías.

- Acefálica; sin gobierno metropolitano, predominio de las administraciones locales municipales.

- Interdependiente: la población genera dependencia entre las unidades, las partes como el complemento.

- Movilidad permanente de los habitantes a favor de las periferias y la dispersión.

Una primera forma de acercarse a estas características lo constituye el análisis de la estructura socioeconómica en esta tabla:
The metropolitan organization generates developed units as extension that makes mobility a must within the metropolitan context every time the transformations by globalization produce a more flexible and uncertain new context.

The metropolitan area characteristics can be summarized:

- Labor flexibility which implies permanent mobility.

- Segregation: Urban structure divided according to social economic distribution.

- Infrastructure: Large roads and railroads infrastructure generated in neighboring territories.

- Acephalic: No central government agencies, mainly local municipalities' administration.

- Interdependent: The cities' population generates creates mutual interdependence between them, parts that complement.

- Permanent mobility: Inhabitants towards the periphery and dispersion.

A first approach to these characteristics is the socio-economic structure analysis from this table below: 
TABLA2. ESTRUCTURA SOCIOECONÓMICA DEL GRAN VALPARAÍSO, ELABORACIÓN PROPIA, PROCESADO EN REDATAM +, A PARTIR DE MODELO ADIMARK/INE 2004.

TABLE 2. SOCIO-ECONOMIC STRUCTURE OF GRAN VALPARAISO, ELABORATED BY THE INVESTIGATION AT REDATAM +, FROM THE ADIMARK/INE 2004 MODEL.

\begin{tabular}{llllll} 
Comuna & ABC1 & C2 & C3 & D & E \\
CONCÓN & 13,16 & 22,97 & 22,81 & 32,23 & 8,83 \\
\hline QUILPUÉ & 7,09 & 25,93 & 26,74 & 31,88 & 8,36 \\
\hline VALPARAíSO & 4,23 & 19,73 & 26,41 & 37,93 & 11,69 \\
\hline VILLA ALEMANA & 5,15 & 25,04 & 28,62 & 32,89 & 8,30 \\
\hline VIÑNA DEL MAR & 12,26 & 25,70 & 24,08 & 29,64 & 8,32 \\
\hline PROMEDIO & 8,4 & 23,9 & 25,7 & 32,9 & 9,1 \\
\hline
\end{tabular}

La estructura socioeconómica segmentada, muestra que Valparaíso disminuye su participación en los grupos $\mathrm{ABCl}$ y $\mathrm{C} 2$ a favor de segmentos de menores ingresos D y E, mientras tanto Viña del Mar capitaliza los sectores altos; a su vez, de acuerdo a la lógica contemporánea del dualismo urbano, también concentra un volumen de pobreza sustantivo.
Segmented socio-economic structure shows that Valparaiso has $A B C 1$ and C2 population in favor of $D$ and $E$ lower income segments. Viña del Mar has the high income sector and according the contemporary logic of urban dualism, it also concentrates a large volume of poverty. 
FIGURA 1. ESTRUCTURA SOCIOECONÓMICA DEL GRAN VALPARAÍSO, ELABORACIÓN PROPIA, PROCESADO EN REDATAM +, A PARTIR DE MODELO ADIMARK/INE 2004.

FIGURE 1. ECONOMIC STRUCTURE OF GRAN VALPARAISO, ELABORATED BY THE INVESTIGATION AT REDATAM +, FROM THE ADIMARK/INE 2004 MODEL.

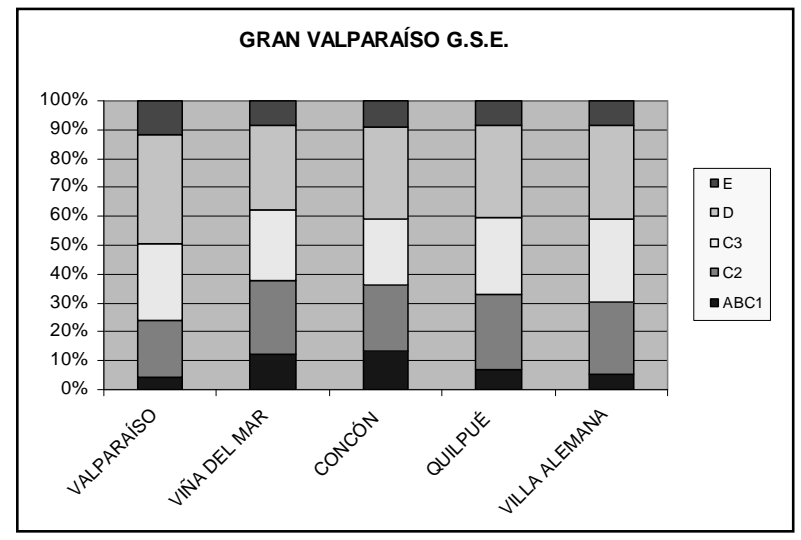

Las ciudades del interior concentran la vitalidad del sistema al concentrar las clases medias, fundamentalmente el grupo C3.

Los grupos que más se desplazan son los grupos C2 y C3, en particular cuando se consulta en el censo de población si estudia o trabaja en esta comuna, las comunas de Quilpué y Villa Alemana se mueven entre un 34 y 27\% respectivamente, un gran fenómeno de desplazamiento pendular entre las comunas del interior y la costa de Valparaíso y Viña del Mar.
The inland cities concentrate the system vitality and hold mainly the middle class C3 group.

The C2 and C3 groups are the ones with more mobility, especially when they were asked in the population census if they study or work within the local community, Quilpue and Villa Alemana move between 34 and $27 \%$ respectively, a great pendular move between the inland and costal Valparaiso and Viña del Mar. 
También estas mismas comunas son las que más incremento intercensal concentran, entre 19\% y 22\% de incremento entre los censos de 1992 y 2002 para Quilpué y Villa Alemana, por contraste se presenta un decrecimiento de población en Valparaíso y un crecimiento de $12 \%$ para Viña del Mar; la media nacional está alrededor de 11 a 12\% .

\section{CONDICIONANTES DE LA MOVILIDAD ACTUAL DEL GRAN VALPARAÍSO}

La intensificación de la movilidad en la macro zona central debido a las grandes inversiones en infraestructura de transporte en los últimos 10 años, puede plantear que el Gran Valparaíso (GV) ha cambiado su patrones de flujo, colgándose del movimiento regional y con ello alimentando nuevas centralidades periféricas. Los accesos al sistema metropolitano medido por el flujo diario del transporte en una estación normal, no son significativos. La entrada al GV de las ciudades del interior tanto del Valle del Aconcagua como de la cuenca del Marga Marga (Limache) no arroja datos relevantes, no así la entrada al sistema desde la Capital de Santiago. Podemos observar que los datos se acrecientan desde la entrada sureste por el desarrollo suburbano de Valparaíso, que concentra el $40 \%$ de la demanda en viviendas del Puerto, apoyada no sólo por una gestión privada sino por el gobierno central como extensión de los límites urbanos de la ciudad.
These communities are also the ones that have the greatest inter-census increase, between 19 and 22\% respectively in the census 1992 and 2002 for Quilpue and Villa Alemana, contrasting Valparaiso population decrease and $12 \%$ growth in Viña del Mar, the national average is around 11 to $12 \%$.

\section{CURRENT MOBILITY CONDITIONS IN GRAN VALPARAISO}

The mobility increased in the macro central zone due to large transport infrastructure investment in the last 10 years. It can be said that Gran Valparaiso (GV) has changed its flow patterns, hanging to the regional mobility and with it feeding new peripheric centralities. The accesses to the metropolitan system measured through the daily transport flow in any station are not meaningful. The inland cities, either from Aconcagua valley or Marga Marga (Limache) basin entrance to $G V$ do not show relevant data, as the entrance to the capital city of Santiago. The data shows that the South-east entrance has higher numbers explained by Valparaiso suburban development that concentrates $40 \%$ of the port housing demand either by private sector or central government management of the city's urban limits extension. 
FIGURA 2. ACCESO AL GRAN VALPARAíSO - FLUJO ABSOLUTO VEHICULAR (IMAGEN SIG, L. ALVAREZ, M. SOTO) FIGURE 2. GRAN VALPARAÍSO ACCESS - ABSOLUTE VEHICULAR FLOW (IMAGE GIS, L. ALVAREZ, M. SOTO)

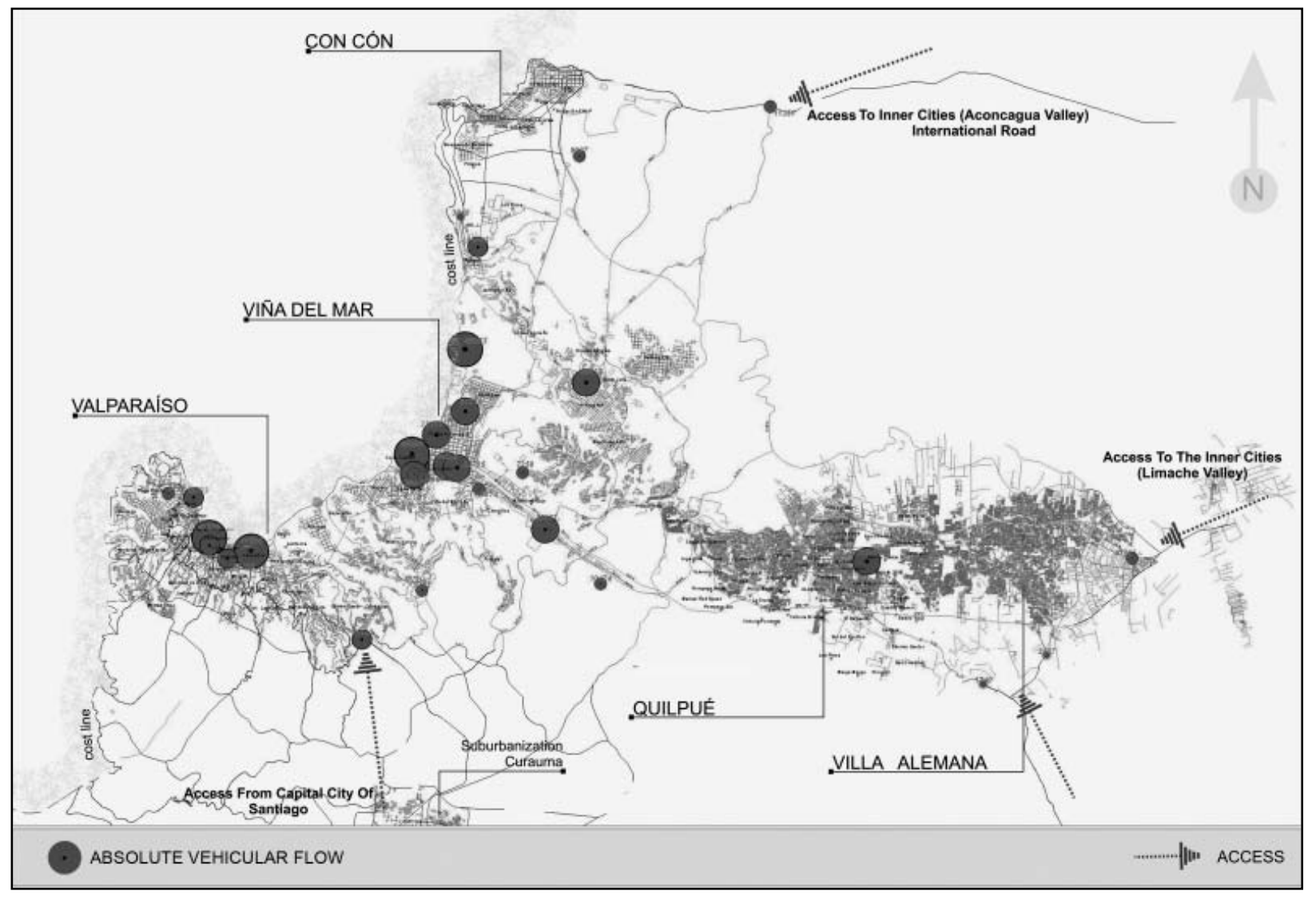


Si centramos nuestro análisis en la movilidad del sistema metropolitano, podemos vislumbrar claramente las dinámicas pendulares entre las ciudades que la conforman. El centro de Valparaíso todavía concentra el mercado del trabajo, gobierno nacional (congreso), regional y comunal, además de poseer todas las labores administrativas y logísticas del Puerto. Viña del Mar sigue concentrando todos los servicios terciarios y las ciudades de Concón, Villa Alemana y Quilpué son por excelencia ciudades dormitorios. Los datos tomados del censo 2002 basado en la pregunta "¿trabajas o estudias en esta comuna?" demuestra que la mayor parte de la población de las ciudades que rodea la zona metropolitana todavía trabaja en el centro de Valparaíso y Viña del Mar, concentrando así todos los flujos matutinos hacia el puerto. El movimiento diario medido por flujo absoluto de vehículos motorizados en diversos puntos del territorio, nos ayuda a entender cuáles son las áreas colapsadas del sistema y donde la red viaria se satura. Esto arroja que la zona pivotante del movimiento pendular del GV se encuentra en el centro de Viña del Mar, en la unión del borde de la ciudad con el borde mar.
If the analysis is focus in the metropolitan system, it can be clearly seen the pendular dynamic between the cities that are part of it. Valparaiso center still concentrates the labor market, national government (congress), regional and communal; besides it holds all the administrative and logistic port services. Viña del Mar still concentrates all the tertiary services and Con Con, Villa Alemana and Quilpue are the dormitory cities. The data were taken from 2002 census based on the question "Do you work or study in the community?" that shows that most of the people who lives in the surrounding cities of the metropolitan zone still work in Valparaiso and Viña del Mar center, concentrating the highest traffic flow towards the port in the mornings. The daily mobility measured by the absolute vehicular flow in different points of the territory helping to understand where the collapsed system's areas are and the roads saturate. This shows that the pivotal zone of the pendular movement of the GV system is in Viña del Mar center at the juncture of the city border with the coastal line. 
FIGURA 3. CENSO DEL AÑO 2002, ¿ESTUDIA O TRABAJA EN ESTA COMUNA? (SIG, L. ÁLVAREZ, M. SOTO) FIGURE 3. 2002 CENSUS, DO YOU WORK OR STUDY IN THE COMMUNITY? (GIS, L. ÁLVAREZ, M. SOTO)

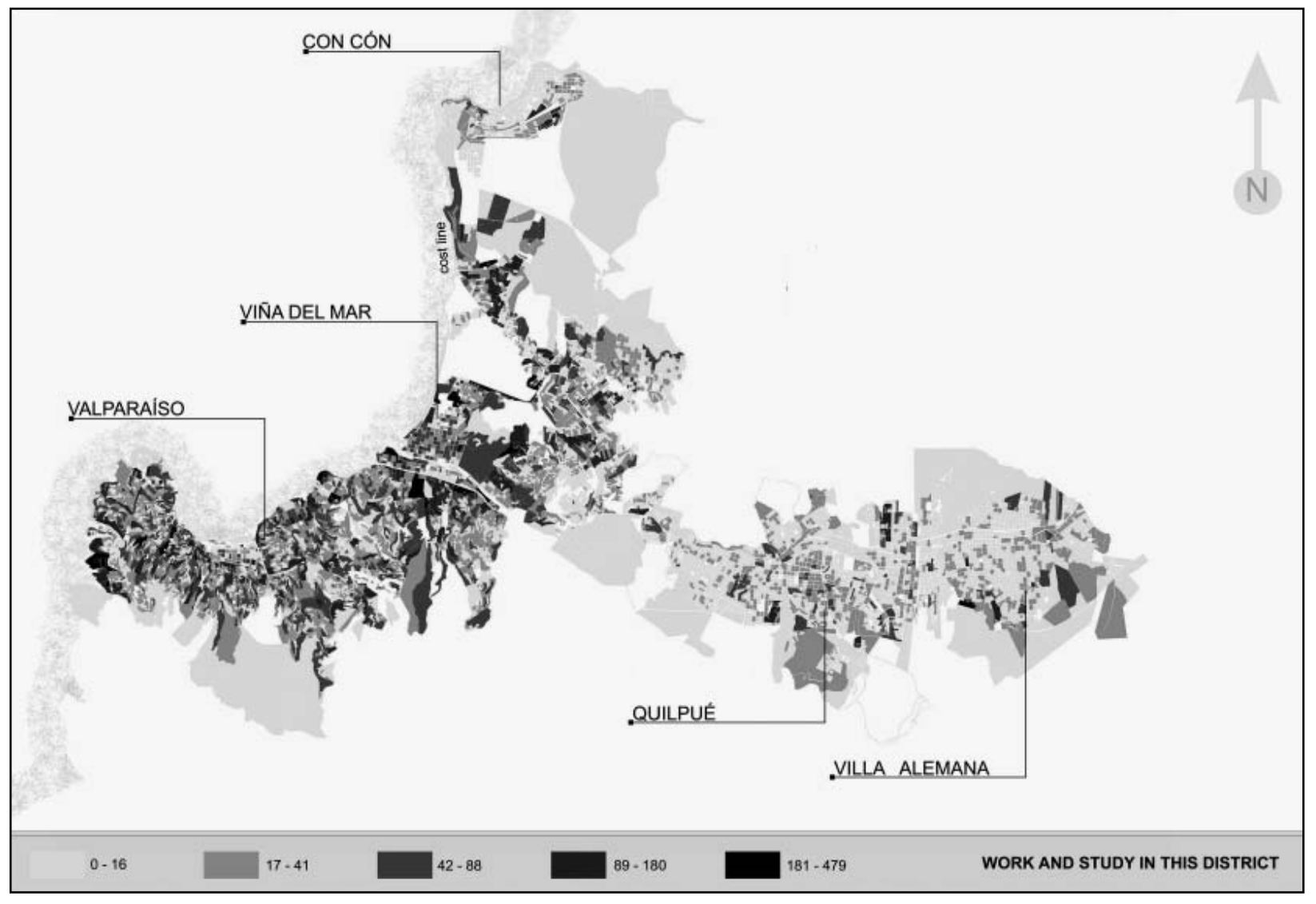


FIGURA4.GRADUACIÓN DELCOLORINVERSAMENTEPROPORCIONALALAINTENSIDAD DELNIVELSOCIOECONÓMICO (SIG, L. ÁLVAREZ , M. SOTO)

FIGURE 4. COLOR GRADUATION INVERSELY PROPORTIONAL TO THE INTENSITY OF THE SOCIO-ECONOMIC LEVEL (GIS, L. ÁLVAREZ , M. SOTO)

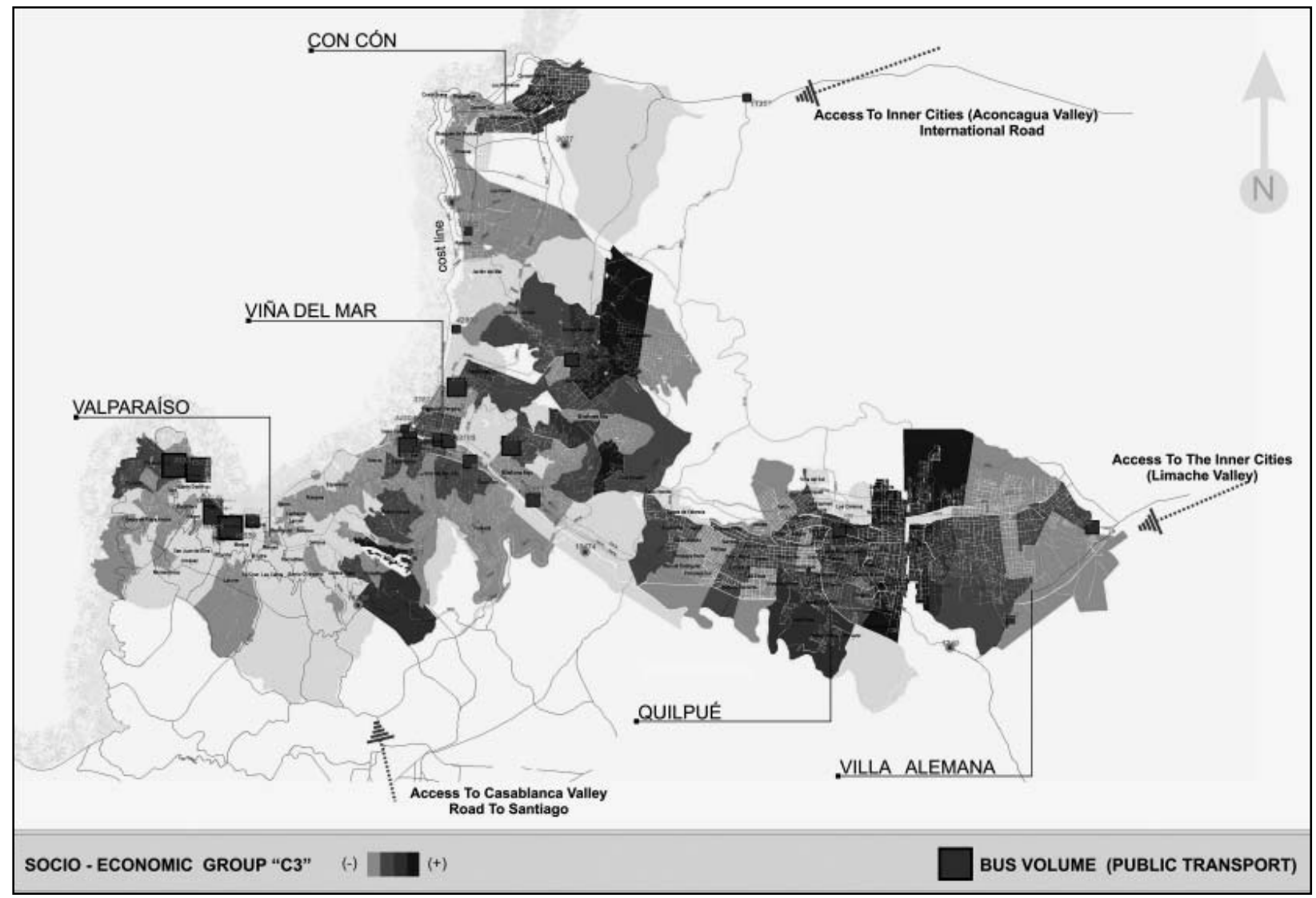


Si analizamos la estructura socioeconómica del sistema metropolitano podemos vislumbrar algunas tendencias de movilidad dadas por los medios de transporte que utilizan mayoritariamente cada una de sus comunas. Valparaíso concentra en su población el grupo socioeconómico más pobre (D) que hace depender a la comuna del transporte público en un 47\%, como también poseer el porcentaje más alto en caminatas (18\%) debido a su estructura morfológica accidentada. El plan del puerto Al contrario, Viña del Mar concentra en su comuna la población $\mathrm{ABCl}$, la cual rodea el centro de la ciudad y se extiende hacia Reñaca, esto hace concentrar dentro del área metropolitana la modalidad de los vehículos privados en un 53\%.
If we analyze the socio-economic structure of the metropolitan system some mobility tendencies can be identified given by the means of transport mainly used in each community. Valparaiso concentrates the poorest sector (D) that makes the community dependent on public transportation $47 \%$ and also it is the highest percentage of people walking $18 \%$ due to Valparaiso's landform structure. The port plan contrasting Viña del Mar concentrates ABC1 population who surround the city center and expands to Reñaca which have the private motor vehicles concentration within the metropolitan area $53 \%$.

FIGURA 5. IMÁGENES DE DISTRIBUCIÓN TERRITORIAL SEGÚN ESTRATOS SOCIOECONÓMICOS DE LA POBLACIÓN (SIG, L. ÁLVAREZ , M. SOTO)

FIGURE 5. TERRITORIAL DISTRIBUTION IMAGES ACCORDING TO THE POPULATION SOCIO-ECONOMIC STRATUM (GIS, L. ÁLVAREZ , M. SOTO)

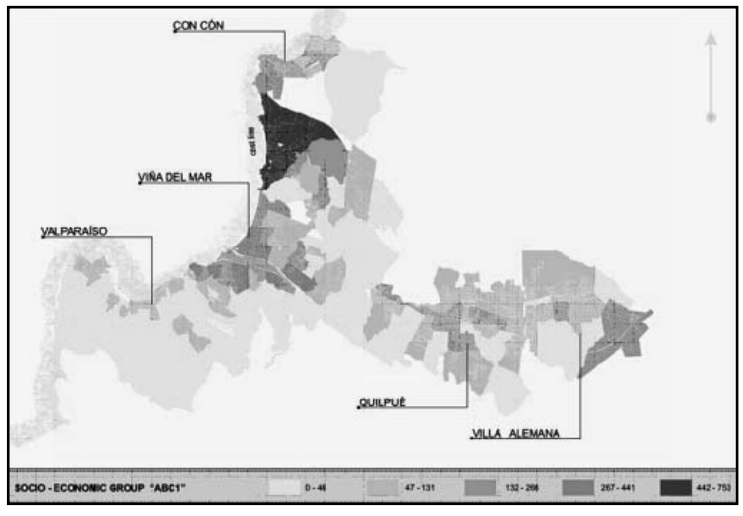

44 revista invi № 65 / Mayo 2009 / Volumen № 24: 19-77

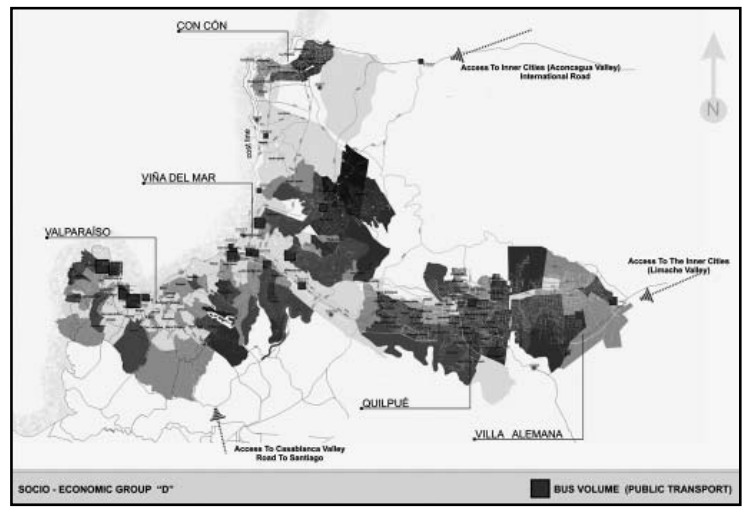

ARTICLE: Spatial Dimension of University Students' Daily Commuting: Greater Valparaiso Case Study / Luis Álvarez A., Lisandro Silva A., Marcela Soto C. 


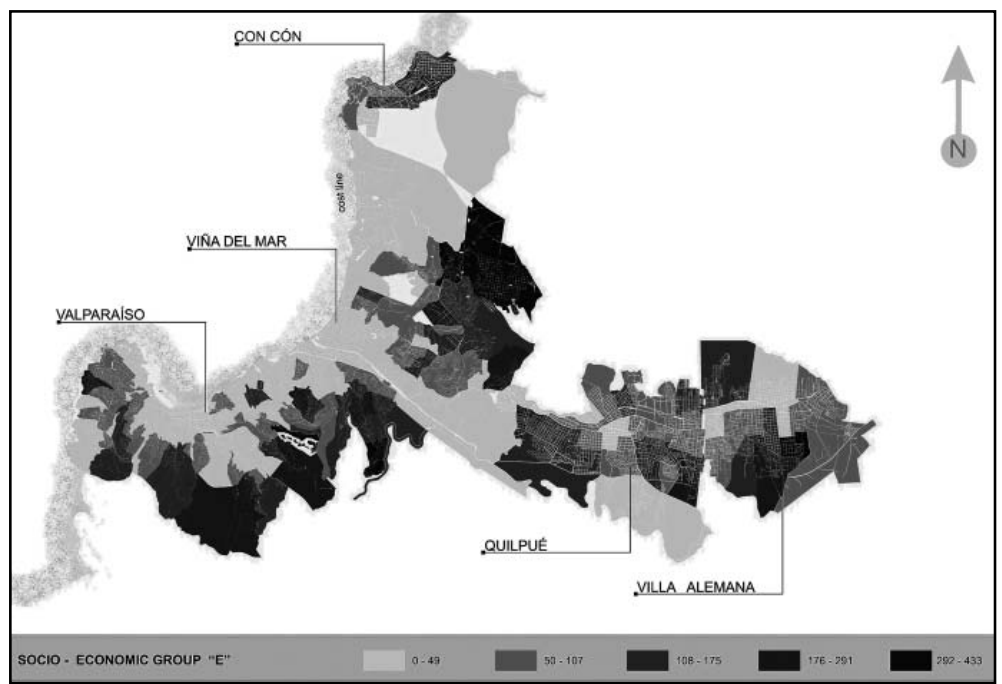

Junto con la caracterización socioeconómica del Gran Valparaíso, es importante para nuestro análisis de la movilidad sustentable, establecer los "cuellos de botella" como configuraciones físicas que determinan en gran medida las condiciones de movilidad de la población y sus expectativas de desarrollo a futuro, como variable de contexto que determinaría la evolución de los patrones de localización "extramuros" de la residencia de los alumnos de la Universidad Santa María.
Togetherwith thesocio-economiccharacterization of Gran Valparaiso, it is important in this analysis the sustainable mobility, establish the "bottle neck" as physical configurations that determines in a great extent the population mobility conditions and its development expectative in the future as part of the context variables that defines the localization of "extramuros" (Out of the city limits0 patterns evolution of the Universidad Santa Maria students residence. 
FIGURA 6. FLUJOS RELACIONADOS A CONGESTIÓN VIAL Y LOCALIZACIÓN DE LA UTFSM (SIG, L. ÁLVAREZ, M. SOTO) FIGURA 6. FLOWS RELATED TO ROADS TRAFFIC AND THE UTFSM LOCATION (GIS, L. ÁLVAREZ, M. SOTO)

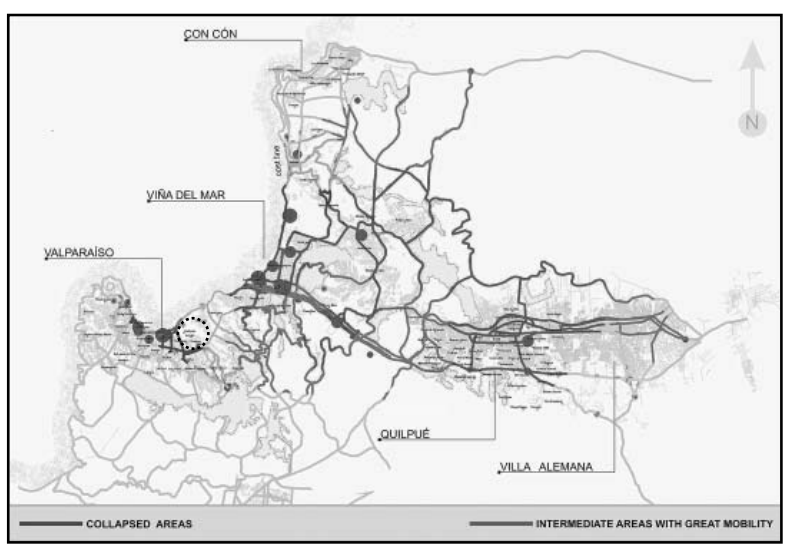

La figura 6 muestra la forma en "T" que determina la estructura de los corredores de transporte que configuran el territorio metropolitano del Gran Valparaíso a lo largo del borde costero y de penetración hacia los valles interiores de Quilpué y Villa Alemana y la localización de la Universidad en una de las ramas del borde costero que conecta Valparaíso con Viña del Mar. Los puntos de congestión que limitan los niveles de servicio de la red vial, se sitúan principalmente en los Planes de Viña y Valparaíso, y en los nodos de sus ejes de acceso o conexión con los cerros respectivos, que es donde muestran las figuras que se produjeron los mayores crecimientos de los flujos vehiculares. Estas dos zonas son los atractores principales de viajes por concentrar en ellas los servicios y comercio que atienden al conjunto metropolitano.

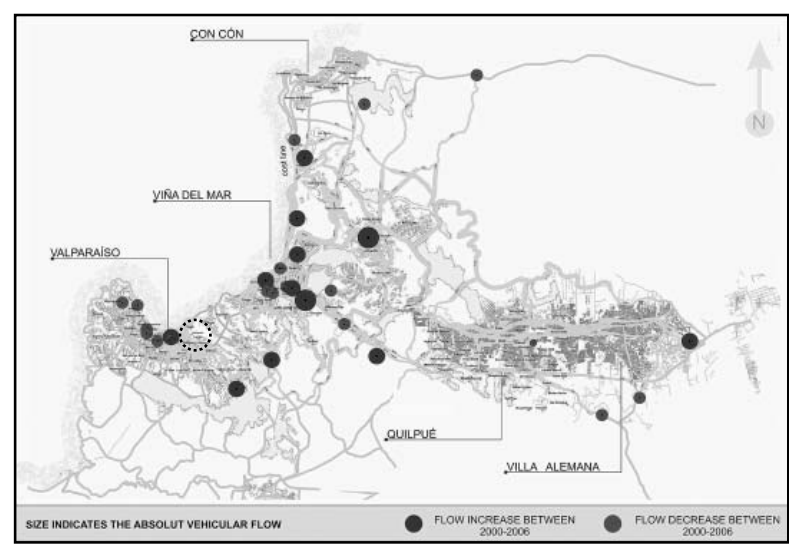

Figure 6 shows the " $T$ " shape that determines the transport corridor structure that configures the Gran Valparaiso metropolitan territory through out the costal border and its extensions to the Quilpue and Villa Alemana valley and the university location on the costal border that connects Valparaiso with Viña del Mar. The traffic jams that restrict road networks services are mainly in Viña del Mar and Valparaiso's plans and its access or connection axis nodal points with the respective hills where the figures show the greatest vehicular flow increase. These two zones are the main attraction points as they concentrate the greatest services and commerce areas that provide the metropolitan area. 


\section{ESTRUCTURA FUNCIONAL DEL GRAN VALPARAÍSO Y RESTRICCIONES A LA MOVILIDAD GLOBAL}

\section{CONDICIONES DE DESARROLLO DE LA MOVILIDAD UNIVERSITARIA}

Mediante un análisis de eslabón principal sobre la base de la información de la Encuesta OrigenDestino de Viajes del Gran Valparaíso ${ }^{10}$, a nivel de Macro-Zonas OD, se identificaron los sistemas espaciales y centralidades del Gran Valparaíso, en un Período de mayor restricción a la movilidad como es la Punta de la Mañana y en los modos de transporte Locomoción Colectiva y Auto Particular.

Se observa en la figura 7 , que se genera una estructura nodal de centralidades de tres niveles. El atractor principal de viajes en la Punta de la Mañana, es el Plan de Valparaíso del cual dependen prácticamente el $70 \%$ de las macro zonas OD. Todo el Borde Costero hasta Reñaca, y el corredor Viña-Quilpué-Villa Alemana. Un nodo atractor de segundo orden, lo constituye el Plan y Centro de Viña del Mar. De él dependen su periferia inmediata sur (Marga-Marga, Viña Oriente y Forestal).

10 SECTRA Zona Norte, 2000

\section{GRAN VALPARAISO FUNCTIONAL STRUCTURE AND GLOBAL MOBILITY RESTRICTIONS}

\section{CONDITIONS OF THE UNIVERSITY MOBILITY DEVELOPMENT}

Analyzing the main link based on Travel Origin-Destiny Survey information of Gran Valparaiso $^{10}$ to Macro-Zones OD level were able to identify the spatial system and Gran Valparaiso centralities in a greater restriction period to the rush hour morning mobility one and the public means of transport and private vehicles.

Figure 7 shows that a three centralized nodal point structures generate. The main attraction point in the morning rush travel is the Valparaiso Plan from which practically $70 \%$ of the OD macro zones depend. The entire costal border up to Reñaca and the Viña-Quilpue Villa Alemana corridor. A second order attraction point is Viña del Mar Center Plan from which its immediate south periphery depends (Marga-Marga, East

10 SECTRA North zone, 2000 
FIGURA 7. ESTRUCTURA FUNCIONAL DEL GRAN VALPARAÍSO, MODO AUTOS PARTICULARES, HORA PUNTA DE LA MAÑANA (L. SILVA, 2007, SOBRE LA BASE DE ENCUESTA OD, SECTRA, 2000)

FIGURE 7. GRAN VALPARAÍSO FUNCTIONAL STRUCTURE, PRIVATE VEHICLES MODALITY, MORNING RUSH HOURS (L. SILVA, 2007, BASED ON OD, SECTRA, 2000 SURVEY)

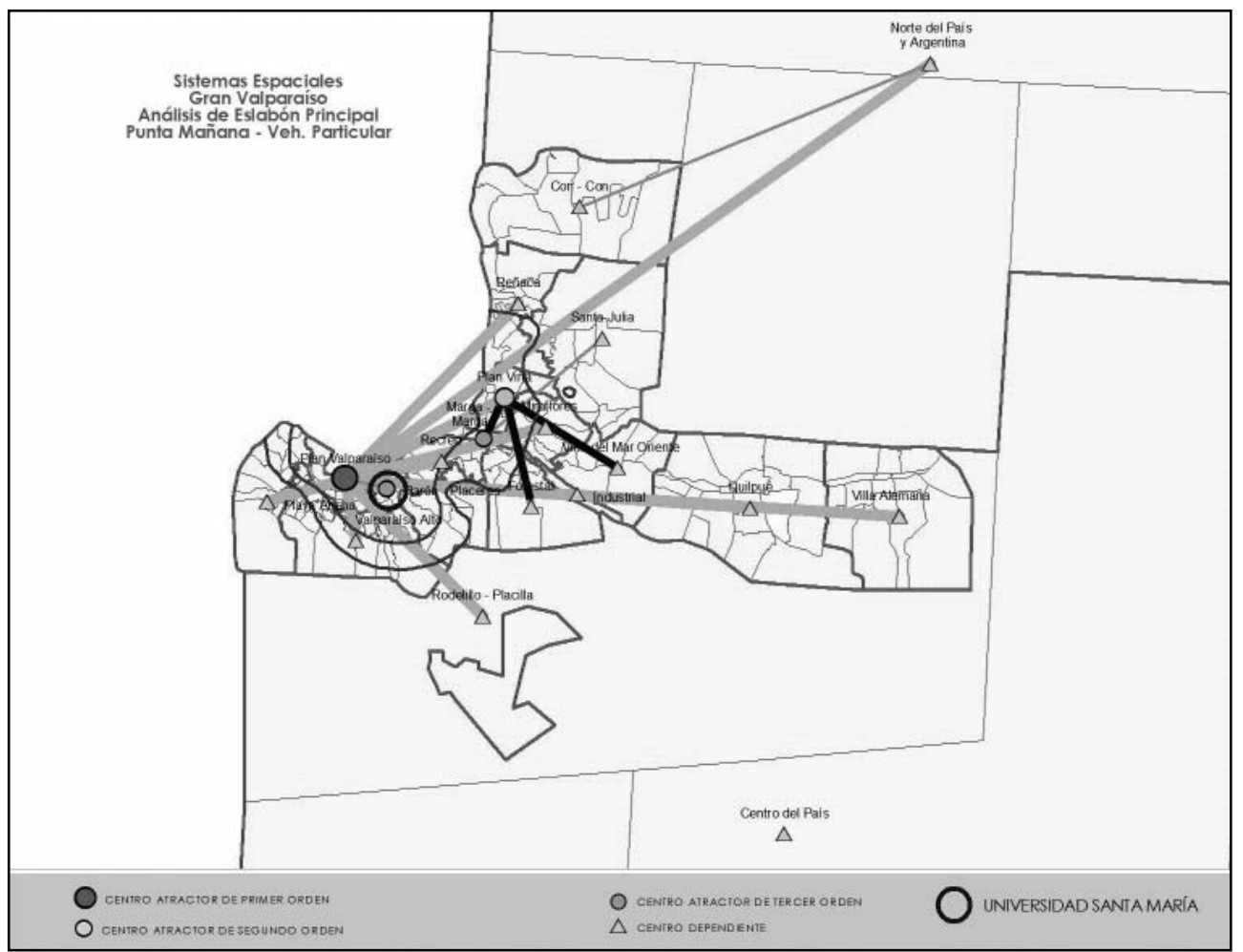


Finalmente, para la movilidad en automóvil particular, aparecen dos centros atractores de tercer orden: Marga-Marga (centro tradicional comercial y de servicios de Viña) y Barón-Placeres, que gravitan sobre Santa Julia el primero, y el Plan de Viña el segundo. Se observa la localización de la Casa Central de la Universidad Santa María en el borde del centro atractor principal del sistema: el Plan de Valparaíso. Constituye, eso sí, un centro atractor de viajes de tercer orden después de los Planes de Valparaíso y Viña del Mar.

Un segundo análisis estructural funcional, se realizó para la movilidad en modo de Locomoción Colectiva y siempre en la Punta de la Mañana. La estructura funcional muestra un patrón similar que el anterior, pero con ciertas variaciones en las relaciones con la periferia inmediata de centros de segundo y tercer orden como el Plan de Viña, que vuelca su influencia hacia Santa Julia y Con Con.

El Plan de Valparaíso continúa siendo el principal atractor de viajes de todo el Conjunto Metropolitano y desequilibrando funcionalmente la dinámica de movilidad en el territorio.

La localización de la Universidad cercana al Plan de Valparaíso en Barón-Placeres, y aledaña al corredor Avda. España entre Valparaíso y Viña, le otorga una ventaja comparativa de accesibilidad, pero además constituye un factor de expansión de localización residencial de los alumnos. Se observa nuevamente, la localización de la Casa Central de la Universidad
Viña and Forestal). Finally for private vehicles mobility two attraction points of third order show up: Marga-Mar (traditional services and commercial center) and Baron-Placeres that gravitates towards first Santa Julia and second Viña Plan. The Santa Maria University main Campus at the border of the system's main attraction point: Plan Valparaiso. It is a third order attraction point after Valparaiso and Viña del Mar plans.

A second functional structural analysis was done for the public transport mobility in morning rush hours. The functional structure shows a similar one to the previous one, but with certain variations related to the immediate periphery of the second and third order centers as Viña Plan that turns its influence towards Santa Julia and Con Con.

Valparaiso Plan still is the main travel attraction point of the whole metropolitan area and functionally unbalances the territory mobility dynamic.

The university location near the Valparaiso Plan on Baron-Placeres and next to España Avenue corridor between Valparaiso and Viña gives accessibility comparative advantage, though also is an expansion factor for students residential location. Once again the Santa 
Santa María en el borde del centro atractor principal del sistema: el Plan de Valparaíso. La diferencia es que en los viajes en Locomoción Colectiva, la localización de la Universidad se produce en un
Maria university main campus location at the border of the system's main attraction point center of the Valparaiso Plan. The difference in the public transportations travel, the university

FIGURA 8. ESTRUCTURA FUNCIONAL DEL GRAN VALPARAÍSO, MODO LOCOMOCIÓN COLECTIVA, HORA PUNTA DE LA MAÑANA (L. SILVA, 2007, SOBRE LA BASE DE ENCUESTA OD, SECTRA, 2000)

FIGURE 8. GRAN VALPARAÍSO FUNCTIONAL STRUCTURE, PUBLIC TRANSPORTATION MODALITY, MORNING RUSH HOURS (L. SILVA, 2007, BASED ON OD, SECTRA, 2000 SURVEY)

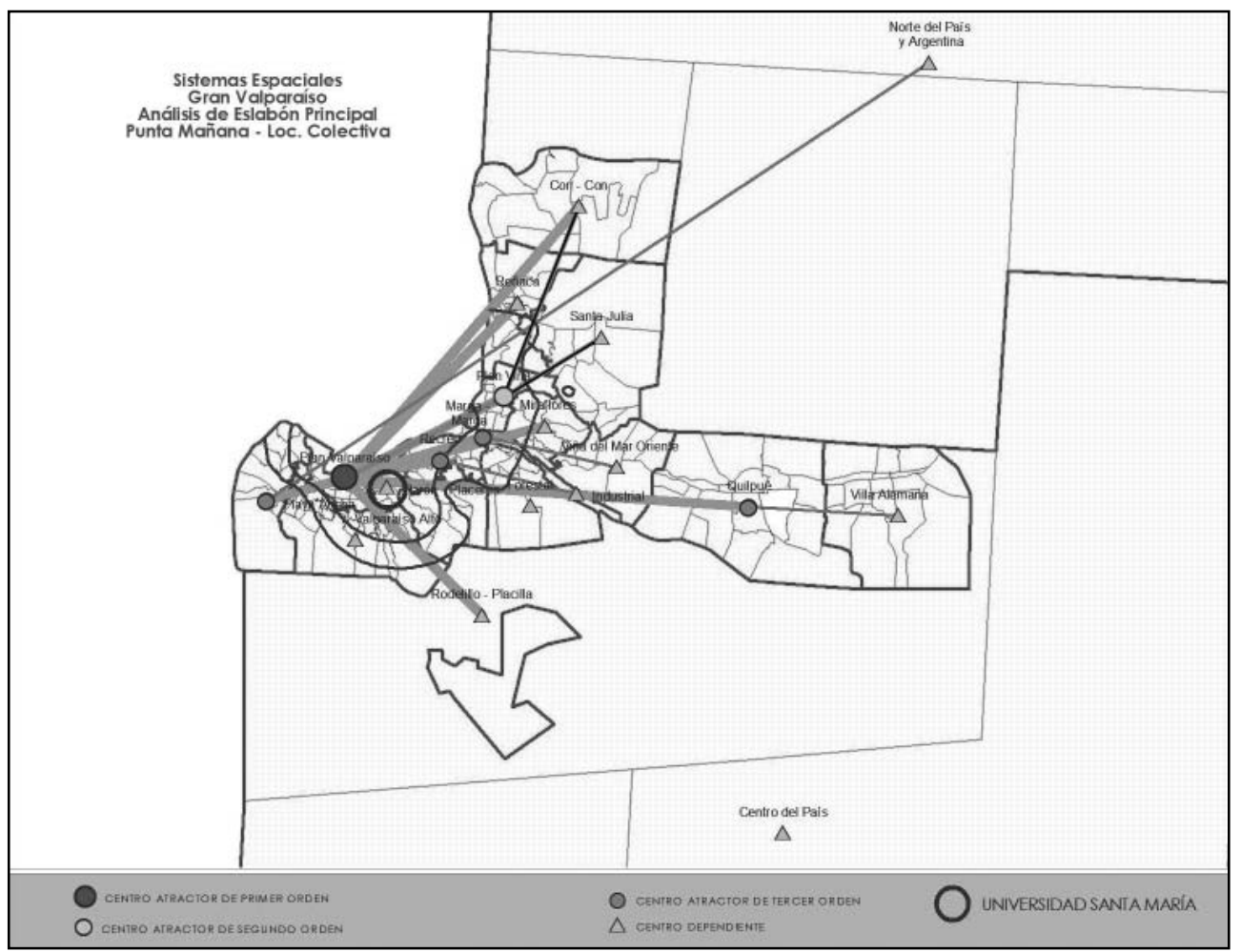


centro totalmente dependiente de los otros centros urbanos, principalmente del Plan de Valparaíso.

Si bien la localización cercana al centro metropolitano de Valparaíso es ventajosa como punto de alta accesibilidad, el problema creciente es que la dinámica de transformación de las actividades del centro metropolitano constituye un "entorno cambiante" para la Universidad, pues tiende a expulsar gradualmente la actividad residencial del centro y en el mejor de los casos se produce el fenómeno de "invasión-sucesión" (nuevas actividades o residentes con mayor poder adquisitivo, expulsan a los antiguos residentes) descrito por los ecólogos urbanos, pues dado el hecho de que los terrenos de mayor accesibilidad y centralidad suben sostenidamente su valor, es esperable que la localización residencial de los alumnos cerca de la Universidad, sea cada vez más costoso, y sean desplazados a localizaciones más lejanas en distancia-tiempo de desplazamiento.

En las tablas de abajo, se confirma el territorio de influencia del emplazamiento de la Universidad Santa María, pues en más de un 50\% los viajes generados y atraídos, se circunscriben a las 4 zonas principales de Plan de Valparaíso, Valparaíso Alto, Plan de Viña y Barón-Placeres, para todos los viajes, en todos los modos y en todos los períodos de día.

En segundo orden aparece el área de influencia, que se desarrolla por el par Alvarez-Viana hasta location is in a totally dependent center of other urban centers, mainly Valparaiso Plan.

Even if the location near Valparaiso metropolitan center is advantageous as high accessibility spot, the problem is that the dynamic transformation of the metropolitan center of activities is a "variable surrounding" for the university as gradually is changing the center residential usage, and in the best possible scenario, produces a "invasion succession" phenomenon (new activities or higher income residents that dislodge the old residents) described by the urban ecologist as the central and better accessibility territories keeps rising their value, it is reasonable that the residential area near the university is becoming more expensive for the university students so they move out to further distance space-time locations.

The tables below confirm the territory of influence of the Santa Maria University as in more than $50 \%$ of the travels generated and attracted subscribe to the Valparaiso Plan main 4 zones Valparaiso Alto, Viña Plan and BaronPlaceres for all the travels in every modality, at any time of the day.

The second order shows the influence area developed by Alvarez Viña to Quilpue and 
Quilpué y Viña del Mar Alto sector Recreo. En la medida que las actividades de servicio y comercio metropolitano van invadiendo el centro de Valparaíso, la tendencia de interacciones hacia la periferia en el eje de Viña del Mar-Quilpué se va consolidando, territorio circunscrito por la isocrona de 30 minutos de viaje desde la Zona 53 (línea verde oscuro en figuras 7 y 8).
Viña del Mar Alto-Recreo sector. As the metropolitan services and commerce grows in Valparaiso center, the interaction tendencies to the periphery Viña del Mar-Quilpue axis is consolidated, circumscribed territory by the Isochronal curve of 30 minutes from the zone 53 (dark green line in figures 7 and 8).

TABLA 3. VIAJES GENERADOS Y ATRAÍDOS POR LA ZOD 53, DE EMPLAZAMIENTO DE LA UNIVERSIDAD SANTA MARÍA TABLE 3. TRAVELS FROM AND TO ZOD 53, SANTA MARÍA UNIVERSITY LOCATION

\begin{tabular}{|c|c|c|c|}
\hline \multicolumn{4}{|c|}{$\begin{array}{l}\text { DESTINOS EN ZONA } 53 \\
\text { (Viajes a USM todos modos y peńodos) }\end{array}$} \\
\hline Macrožna Origen & Viajes & $\%$ & $\%$ acum. \\
\hline Plan Valparaíso & 1.031 & $18,7 \%$ & $18,7 \%$ \\
\hline Valparaíso Alto & 986 & $17,9 \%$ & $36,7 \%$ \\
\hline Plan Viña & 592 & $10,8 \%$ & $47,4 \%$ \\
\hline Barón - Placeres & 529 & $9,6 \%$ & $57,1 \%$ \\
\hline Quilpué & 367 & $6,7 \%$ & $63,7 \%$ \\
\hline Santa Julia & 326 & $5,9 \%$ & $69,7 \%$ \\
\hline Recreo & 325 & $5,9 \%$ & $75,6 \%$ \\
\hline Forestal & 304 & $5,5 \%$ & $81,1 \%$ \\
\hline Playa Ancha & 229 & $4,2 \%$ & $85,3 \%$ \\
\hline Rodelillo - Placilla & 193 & $3,5 \%$ & $88,8 \%$ \\
\hline Marga - Marga & 190 & $3,5 \%$ & $92,2 \%$ \\
\hline Villa Alemana & 133 & $2,4 \%$ & $94,7 \%$ \\
\hline Reñaca & 91 & $1,7 \%$ & $96,3 \%$ \\
\hline Viña del Mar Oriente & 88 & $1,6 \%$ & $97,9 \%$ \\
\hline Sur del País & 62 & $1,1 \%$ & $99,0 \%$ \\
\hline Miraflores & 53 & $1,0 \%$ & $100,0 \%$ \\
\hline TOTAL & 5.499 & $100 \%$ & \\
\hline
\end{tabular}

VIAJ ES GENERADOS EN ZONA 53

(Viajes desde USM a todos modos y peńodos)

\begin{tabular}{|c|c|c|c|}
\hline Macrozona Destino & Víajes & $\%$ & $\%$ acum. \\
\hline Plan Valparaíso & 1.169 & $21,3 \%$ & $21,3 \%$ \\
\hline Valparaíso Alto & 901 & $16,4 \%$ & $37,6 \%$ \\
\hline Plan Viña & 592 & $10,8 \%$ & $48,4 \%$ \\
\hline Barón - Placeres & 529 & $9,6 \%$ & $58,0 \%$ \\
\hline Recreo & 392 & $7,1 \%$ & $65,2 \%$ \\
\hline Quilpué & 367 & $6,7 \%$ & $71,8 \%$ \\
\hline Forestal & 304 & $5,5 \%$ & $77,4 \%$ \\
\hline Santa Julia & 269 & $4,9 \%$ & $82,3 \%$ \\
\hline Playa Ancha & 229 & $4,2 \%$ & $86,4 \%$ \\
\hline Rodelillo - Placilla & 193 & $3,5 \%$ & $89,9 \%$ \\
\hline Villa Alemana & 133 & $2,4 \%$ & $92,3 \%$ \\
\hline Marga - Marga & 127 & $2,3 \%$ & $94,7 \%$ \\
\hline Reñaca & 91 & $1,7 \%$ & $96,3 \%$ \\
\hline Viña del Mar Oriente & 88 & $1,6 \%$ & $97,9 \%$ \\
\hline Sur del País & 62 & $1,1 \%$ & $99,0 \%$ \\
\hline Miraflores & 53 & $1,0 \%$ & $100,0 \%$ \\
\hline TOTAL & 5.499 & $100 \%$ & \\
\hline
\end{tabular}

Fuente: Sobre Base de MERVAL, SECTRA NORTE, 2000 


\section{DETERMINANTES DE LA LOCALIZACIÓN RESIDENCIAL UNIVERSITARIA: DINÁMICA DE LA OFERTA HABITACIONAL EN EL GRAN VALPARAÍSO}

Elstock de viviendas existentes constituye el porcentaje mayor de la oferta de arrendamientos para estudiantes universitarios, en forma de pensiones y formas comunitarias de arrendamiento de departamentos nuevos. Del stock de viviendas en el Gran Valparaíso, el 38,3\% se localiza en Viña del Mar, el 31,1\% en Valparaíso, el resto en las Comunas de Quilpué (15,2\%), Villa Alemana (11,0\%) y Con Con $(4,4 \%)$.

Parte importante de la oferta urbana habitacional para la demanda residencial de estudiantes universitarios y turistas, es explicada por el mercado del arriendo de viviendas. La tabla inferior, muestra las personas arrendatarias con educación universitaria, por tipo de vivienda y comuna del Gran Valparaíso.

\section{UNIVERSITY STUDENTS RESIDENTIAL LOCATION DETERMINERS: HOUSING OFFER DYNAMIC IN GRAN VALPARAISO}

The existing housing stock is the greater percentage or rent offer for university students, either in guest house and room mates sharing housing modality of new apartments. Out of Gran Valparaiso housing stock 38\% is in Viña del Mar, 31.1\% in Valparaiso, the rest is in Quilpue (15.2\%). Villa Alemana (11.0\%) and Con Con (4.4\%).

Most of the urban housing offer for the university students and tourist residential demand is explained by the real estate renting market. The table below shows people who rents with higher education by housing type and Gran Valparaiso community.

\section{TABLA 4. VIVIENDAS ARRENDADAS POR PERSONAS, CON MÁS DE 12 AÑOS DE ESCOLARIDAD, POR COMUNAS Y TIPO DE VIVIENDA, DEL GRAN VALPARAíSO (CENSO, 2002)}

TABLE 4. RENTED HOUSING BY PEOPLE WITH MORE THAN 12 YEARS OF EDUCATION, BY COMMUNITY AND TYPE OF HOUSING IN GRAN VALPARAISO (CENSUS, 2002)

\begin{tabular}{|c|c|c|c|c|c|c|c|c|c|c|c|}
\hline $\begin{array}{l}\text { Nombre de la } \\
\text { Comuna }\end{array}$ & Casa & $\begin{array}{c}\text { Departamento } \\
\text { en edificio }\end{array}$ & $\left|\begin{array}{c}\text { Piezas en casa } \\
\text { antigua o } \\
\text { conventillo }\end{array}\right|$ & $\begin{array}{l}\text { Mejora, } \\
\text { mediagua }\end{array}$ & Rancho, choza & $\begin{array}{c}\text { Móvil (carpa, } \\
\text { vagón, } \\
\text { container, bote, } \\
\text { lancha, similar) }\end{array}$ & $\begin{array}{l}\text { Otro tipo de } \\
\text { vivienda } \\
\text { particular }\end{array}$ & $\begin{array}{c}\text { Vivienda } \\
\text { colectiva } \\
\text { (Residencial, } \\
\text { Hotel, Hospital, } \\
\text { etc.) }\end{array}$ & $\begin{array}{c}\text { Viajeros (no es } \\
\text { considerado } \\
\text { vivienda) }\end{array}$ & V1_T & $\%$ \\
\hline Valparaíso & 60605 & 16341 & 1410 & 1660 & 110 & 13 & 290 & 654 & 7 & 81090 & $31,1 \%$ \\
\hline Concón & 8090 & 3049 & 65 & 209 & 15 & 3 & 92 & 38 & 0 & 11561 & $4,4 \%$ \\
\hline Quilpué & 32329 & 5960 & 149 & 880 & 59 & 1 & 98 & 83 & 0 & 39559 & $15,2 \%$ \\
\hline Villa Alemana & 25194 & 2377 & 74 & 822 & 46 & 6 & 67 & 60 & 0 & 28646 & $11,0 \%$ \\
\hline Viña del Mar & 59956 & 36441 & 547 & 1633 & 91 & 53 & 305 & 593 & 3 & 99622 & $38,2 \%$ \\
\hline $\begin{array}{l}\text { TOTAL } \\
\%\end{array}$ & $\begin{array}{r}\mathbf{1 8 6 1 7 4} \\
71,5 \%\end{array}$ & $\begin{array}{l}64168 \\
24,6 \%\end{array}$ & $\begin{array}{l}\mathbf{2 2 4 5} \\
0,9 \%\end{array}$ & $\begin{array}{l}\mathbf{5 2 0 4} \\
2,0 \%\end{array}$ & $\begin{array}{r}321 \\
0,1 \%\end{array}$ & $\begin{array}{r}76 \\
0,0 \%\end{array}$ & $\begin{array}{r}852 \\
0,3 \%\end{array}$ & $\begin{array}{l}1428 \\
0,5 \%\end{array}$ & $\begin{array}{r}10 \\
0,0 \%\end{array}$ & $\begin{array}{l}\mathbf{2 6 0 4 7 8} \\
100,0 \%\end{array}$ & $0,0 \%$ \\
\hline
\end{tabular}


Se muestra que las viviendas colectivas constituyen un universo reducido $(0,5 \%)$ respecto del total de viviendas, y dentro de éstas, Valparaíso y Viña del Mar son las que concentran la oferta con 654 $(45,8 \%)$ y 593 (41,5\%), de las viviendas colectivas (pensiones, hoteles y hospitales). Además 2.245 viviendas $(0,9 \%)$, corresponden a arriendos en Piezas de Edificios Antiguos o Conventillos, y se concentran principalmente en Valparaíso (62,8\%) y Viña del Mar (24,4\%). Las unidades de Departamentos arrendadas son 64.168 y corresponden al 24,6\% del total de viviendas en estas condiciones. Los porcentajes se invierten, pues un 56,8\% corresponden a Viña del Mar y un 25,5\% a Valparaíso. Las casas en arriendo a personas con estudios Universitarios, son alrededor de 186.174 y corresponden a un $71,5 \%$ del total. Valparaíso representa el 32,6\%, Viña del Mar 32,2\% y Quilpué el $17,4 \%$.

La información del Censo del 2002, permite relevar los factores importantes que explican la forma de crecimiento del Gran Valparaíso, y su oferta residencial localizada. Los datos muestran el grado de correlación que existe entre la localización de la oferta residencial en el gran Valparaíso, y la localización de los alumnos universitarios. Finalmente, analizaremos la localización residencial universitaria de los alumnos de la USM, incorporando la oferta inmobiliaria que se da en el Gran Valparaíso, pues explica el auge de la compra de departamentos en Viña, para renta de residencias universitarias y de
It shows the shared housing is a reduced universe of (0.5\%) related to the total housing and within this category Valparaiso and Viña del Mar with 654 (45.8\%) and 593 (41.5\%) concentrate the housing offer (guest houses, hotels and hospitals). 2,245 (0.9\%) houses are rooms in old houses for rent or tenements and are mainly concentrated in Valparaiso (62.8\%) and Viña del Mar (24.4\%). Apartment units rented are 64.168 (24.6\%) of the total housing in this conditions. The percentages interchange as $56.8 \%$ are in Viña del Mar and $25.5 \%$ in Valparaiso. Houses that are for rent for people with higher education are around 189.174 and are $71.5 \%$ of the total offer. Valparaiso has $32.2 \%$ and Quilpue $17.4 \%$.

The census 2002 information reveals the important factors that explain the growth in Gran Valparaiso and its localized residential offer. The data shows the existing correlation level between the housing offer location in Gran Valparaiso and the university students' location. Finally, it is analyzed USM university students' residential location, adding the real estate offers within the Gran Valparaiso because it explains the apartment boom buying in Viña to rent as university students residence and tourism especially by the costal 
turismo, sobre todo en el Borde Costero en el Plan de Viña y hacia el Norte del Gran Valparaíso.

Los tres últimos Censos muestran una tendencia al estancamiento del crecimiento poblacional de Viña y Valparaíso y un crecimiento importante de las comunas periféricas de Con Con, Quilpué y Villa Alemana. Sin embargo en Viña, se ve un crecimiento sostenido de la oferta inmobiliaria de departamentos, y según los datos del sector, se trata predominantemente de segundas viviendas ligadas a la demanda residencial de turistas y en forma complementaria, de estudiantes universitarios. border in Viña Plan towards the North of Gran Valparaiso.

The last three census show a stagnation tendency of the population growth in Viña and Valparaiso and an important increase in the peripheric communities of Con Con, Quilpue and Villa Alemana. Nevertheless Viña has a steady growth of the real estate apartment offer and according to the sector data is predominantly second houses linked to tourist residential demand and complementary to university students.

TABLA 5. EVOLUCIÓN DE LA POBLACIÓN EN LOS ÚLTIMOS 20 AÑOS EN LAS CIUDADES DE LA INTERCOMUNA DE VALPARAíSO (FUENTE: L. SILVA 2007, SOBRE LA BASE DE INFORMACIÓN DEL PLAN DE DESARROLLO URBANO REGIONAL DE VALPARAÍSO, SEREMI MINVU, V REGIÓN)

TABLE 5. POPULATION EVOLUTION IN THE LAST 20 YEARS IN THE CITIES OF THE INTER-COMMUNITY OF VALPARAISO (SOURCE: L. SILVA 2007, BASED ON PLAN DE DESARROLLO URBAN REGIONAL DE VALPARAÍSO INFORMATION, SEREMI MINVU, V REGION)

\begin{tabular}{|l|l|r|r|r|}
\hline Comuna & localidad & \multicolumn{1}{|c|}{ POB:82 } & \multicolumn{1}{c|}{ POB92 } & \multicolumn{1}{c|}{ POB:02 } \\
\hline Viña del Mar & Viña del Mar & 249.977 & 285.285 & 286.931 \\
\hline Valparaíso & Valparaíso & 265.718 & 274.228 & 263.499 \\
\hline Quilpué & Quilpué & 84.291 & 102.233 & 126.893 \\
\hline Villa Alemana & Villa Alemana & 55.818 & 70.663 & 94.802 \\
\hline Viña del Mar - Con Con & Con Con & 13.325 & 18.304 & 31.558 \\
\hline \hline TOTAL & 669.129 & 750.713 & 803.683 \\
Variación \% & & $12,2 \%$ & $7,1 \%$ \\
\hline Fuente: INE
\end{tabular}




\section{FIGURA 9. EVOLUCIÓN DE LA POBLACIÓN, POR COMUNAS DEL GRAN VALPARAÍSO (FUENTE: INE)}

\section{FIGURE 9. POPULATION EVOLUTION, BY COMMUNITY IN GRAN VALPARAISO (SOURCE: INE)}

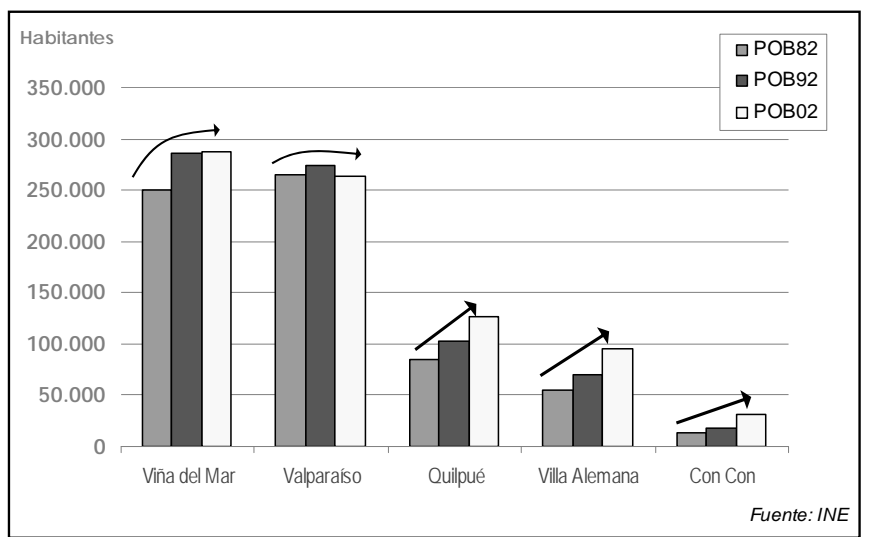

Esta dinámica de crecimiento de densificación de la edificación y disminución de población residente, se refleja también en la contabilidad de las superficies urbanizadas en el mismo territorio. Los incrementos en las superficies urbanas, entre los años 1991 y 2001, superan en todos los casos, más de un 50\%, incluso en las ciudades que no arrojan crecimientos demográficos importantes como Valparaíso y Viña del $\operatorname{Mar}^{11}$

Esta situación se torna crítica, si se compara con las limitantes geográficas que refleja el sistema urbano para su crecimiento, y la estructura funcional

11 SEREMI MINVU, Plan de Desarrollo Urbano Regional de Valparaíso, V Región.
This building densification growth dynamic and residents population decrease also reflects on the urbanized surface numbers in the same territory. The increase of the urbanized surface between the years 1991 and 2001 surpasses in each case, more than $50 \%$ even in cities that numbers do not show an important demographic growth such as Valparaiso and Viña del Mar ${ }^{11}$.

This situation becomes critical if you compare it with the geographical limitations reflected in the urban system for its growth and the mono-

11 SERVIU MIMVU, Plan de Desarrollo Urbano Regional Valparaiso [Regional Valparaiso Urban Development Plan], V Region. 
monocéntrica antes mencionada, que produce problemas crecientes de movilidad para la población, las actividades económicas y los turistas, situación que afecta la localización central de la universidad. centric functional structure above mentioned that produces growing mobility problems for the population, economic activities and tourists that affect the central location of the university.

TABLA 6. PROYECCIONES DE CONSUMO DE SUPERFICIES 20010, SEGÚN MINVU V REGIÓN

TABLE 6. SURFACES CONSUMPTION PROJECTION 20010, ACCORDING MINVU V REGION

\begin{tabular}{l|r|r|r|r|}
\hline COMUNA & $\begin{array}{l}\text { PROY. EDIFCACIÓN } \\
\text { PROODUCTIVA (Há) }\end{array}$ & $\%$ & $\begin{array}{c}\text { PROY. EDIFCACIÓN } \\
\text { RESIDENCIAL (Há) }\end{array}$ & $\%$ \\
\hline VALPARAÍSO & 240,14 & $22,7 \%$ & 606,93 & $20,6 \%$ \\
VIÑA DEL MAR & 368,94 & $34,9 \%$ & 800,71 & $27,2 \%$ \\
QUILPUÉ & 168,70 & $16,0 \%$ & 507,41 & $17,3 \%$ \\
VILLA ALEMANA & 24,43 & $2,3 \%$ & 321,15 & $10,9 \%$ \\
CONCÓN & 254,70 & $24,1 \%$ & 703,82 & $23,9 \%$ \\
\hline TOTAL & $\mathbf{1 0 5 6 , 9 1}$ & $100,0 \%$ & $\mathbf{2 9 4 0 , 0 2}$ & $100,0 \%$ \\
\hline
\end{tabular}

\section{OFERTA EN MERCADO PRIVADO DE LA VIVIENDA Y LOCALIZACIÓN RESIDENCIAL UNIVERSITARIA}

Tomando como base de datos, las series estadísticas de ventas de departamentos y viviendas de la CCHC, que registran los stocks de ventas efectivos en el horizonte de los años 2003 a la fecha, permite en dicho horizonte determinar el comportamiento de las ventas inmobiliarias y el comportamiento efectivo del mercado en la intercomuna del Gran Valparaíso, así como su tamaño.

ARTíCULO: Dimensión Espacial de la Movilidad Cotidiana Universitaria: El Caso del Gran Valparaíso / Luis Álvarez A., Lisandro Silva A., Marcela Soto C.

\section{HOUSING PRIVATE MARKET OFFER AND UNIVERSITY STUDENTS RESIDENTIAL LOCATION}

Taking the data base as starting point, the statistical series of apartment and housing sales of the CCHC, that register the real sales stocks on the 2003 horizons up to now shows that that horizon determines the real estate sales behavior and the real market behavior in the intercommunity in Gran Valparaiso as its size.

revista invi № 65 / May 2009 / Volume $\mathrm{N}^{0} 24: 19-77$ 
TABLA 7. MERCADO HABITACIONAL EN EL GRAN VALPARAÍSO (UNIDADES VENDIDAS ANUALES, FUENTE: CCHC.)

TABLE 7. HOUSING MARKET IN GRAN VALPARAISO (UNITS SOLD, SOURCE: CCHC.)

\begin{tabular}{lllll} 
Tipo Vivienda & 2004 & 2005 & 2006 & a Abr-07 \\
DEPTOS & 2163 & 2154 & 1983 & 812 \\
\hline CASAS & 1283 & 1446 & 1061 & 405 \\
\hline TOTAL & 3446 & 3600 & 3044 & 1217 \\
\hline
\end{tabular}

El mercado habitacional se caracteriza por dos segmentos de oferta: las viviendas unifamiliares y los departamentos. En la tabla anterior, se muestra el volumen de ventas en unidades de departamentos y viviendas para los años 2004 a 2006 y hasta el mes de abril del año 2007. De acuerdo con dicha información, la venta promedio anual alcanza los 2.100 departamentos y 1.263 viviendas, con un total de 3.363 unidades anuales vendidas, que corresponde aproximadamente a un 1,4\% del total de stock de viviendas en arriendo de la Tabla 4 anterior, entre casas y departamentos.
FIGURA 10. OFERTA INMOBILIARIA EN EL GRAN VALPARAÍSO, POR SECTORES URBANOS (FUENTE: L. SILVA SOBRE LA BASE DE DATOS DE LA CCHC.)

FIGURE 10. GRAN VALPARAÍSO REAL ESTATE OFFER, BY URBAN SECTOR (SOURCE: L. SILVA BASED ON CCHC DATA.)

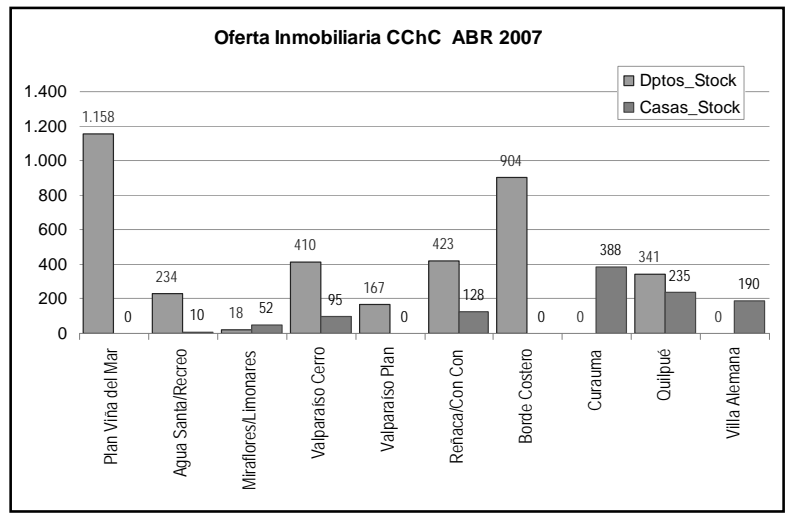

The housing market characterizes by two offer segments: single family houses and apartments. The table above shows the volume of sold units per apartment and houses between 2004 and 2006 and up to April 2007. According to this information, the average annual sales is 2,100 apartments and 1,263 houses, with a total of 3,363 annual units sold that are approximately $1,4 \%$ of the rented residence total stock in table 3 between houses and apartments. 
La distribución espacial del mercado habitacional privado, se realiza sobre la base de datos de la Cámara Chilena de la Construcción, que acumula estadísticas de 10 sectores urbanos del Gran Valparaíso, según se ven en la base de la figura anterior. Una muestra para el mes de abril de 2007, se observa que en el mercado de Departamentos los sectores que concentran la oferta inmobiliaria son en orden decreciente: Plan de Viña, Borde costero, Reñaca-Con Con, y Valparaíso Cerros. En el mercado de viviendas, los sectores que concentran más del 50\% de la oferta, son Curauma, Quilpué y Villa Alemana, en orden decreciente.
The private market spatial distribution it is done through the Camara Chilena de la Construccion (Chilean Chamber of Construction) that has statistics of 10 urban sectors of Gran Valparaiso as it shows in the above figure. The month of April 2007 shows that the apartment market concentrates the real estate offer in decreasing order: Viña Plan, Costal Border, Reñaca-Con Con and Valparaiso Hills. The housing market concentrates more than 50\% of the offer in decreasing order: Curauma, Quilpue and Villa Alemana.

FIGURA 11. OFERTA INMOBILIARIA EN PORCENTAJES DEL STOCK POR SECTORES URBANOS DEL GRAN VALPARAÍSO (FUENTE: L. SILVA, CCHC, ABRIL 2007)

FIGURE 11. REAL ESTATE STOCK PERCENTAGE OFFER PER URBAN SECTORS IN GRAN VALPARAÍSO (SOURCE: L. SILVA, CCHC, APRIL 2007)

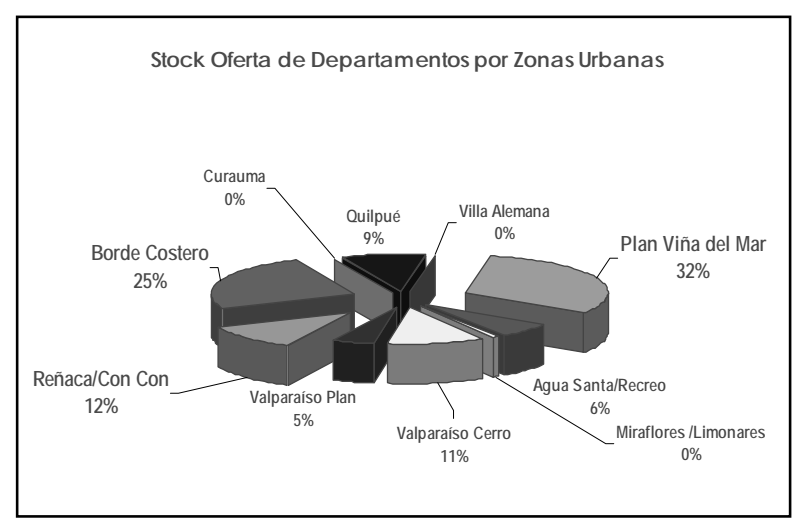

ARTíCULO: Dimensión Espacial de la Movilidad Cotidiana Universitaria: El Caso del Gran Valparaíso / Luis Álvarez A., Lisandro Silva A., Marcela Soto C.

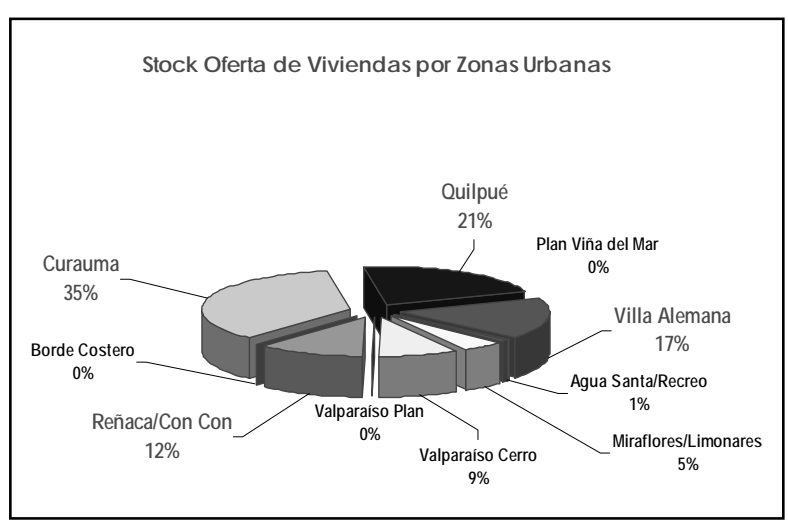

revista invi № 65 / May 2009 / Volume № 24: 19-77 
La figura muestra que el $69 \%$ de la oferta de departamentos, se concentra en las zonas de atracción turística, del Plan de Viña, Borde Costero y ReñacaCon Con. En la oferta de viviendas, esta se concentra en un $73 \%$ en los sectores de Curauma, Quilpué y Villa Alemana, es decir en la periferia del Gran Valparaíso, oferta que se asocia mayoritariamente a la demanda habitacional de los residentes de conjunto urbano, no necesariamente ligados a segundas viviendas o rentas relacionadas con la oferta turística de Viña del Mar, como ocurre con los departamentos.
The figure shows that $69 \%$ of the apartment offer concentrates in the tourist attraction zone of Viña Plan, Costal Border and ReñacaCon Con. The housing offer is concentrated 73\% in Curauma, Quilpue and Villa Alemana sector, in other words at the periphery of Gran Valparaiso. This offer is mainly linked to the urban residential housing need, not necessarily related to renting link to Viña del Mar tourist demand as it is the trend with apartments.

FIGURA 12. VENTAS MENSUALES DE DEPARTAMENTOS Y VIVIENDAS EN EL GRAN VALPARAÍSO, ENTRE LOS MESES DE ABRIL DE 2003 Y ABRIL DE 2007 (L. SILVA, CONSTRUCCIÓN PROPIA A PARTIR DE DATOS DE LA CCHC.)

FIGURE 12. GRAN VALPARAÍSO APARTMENT AND HOUSING MONTHLY SALES, APRIL 2003 Y APRIL DE 2007 (L. SILVA, TAKEN FROM CCHC DATA.)

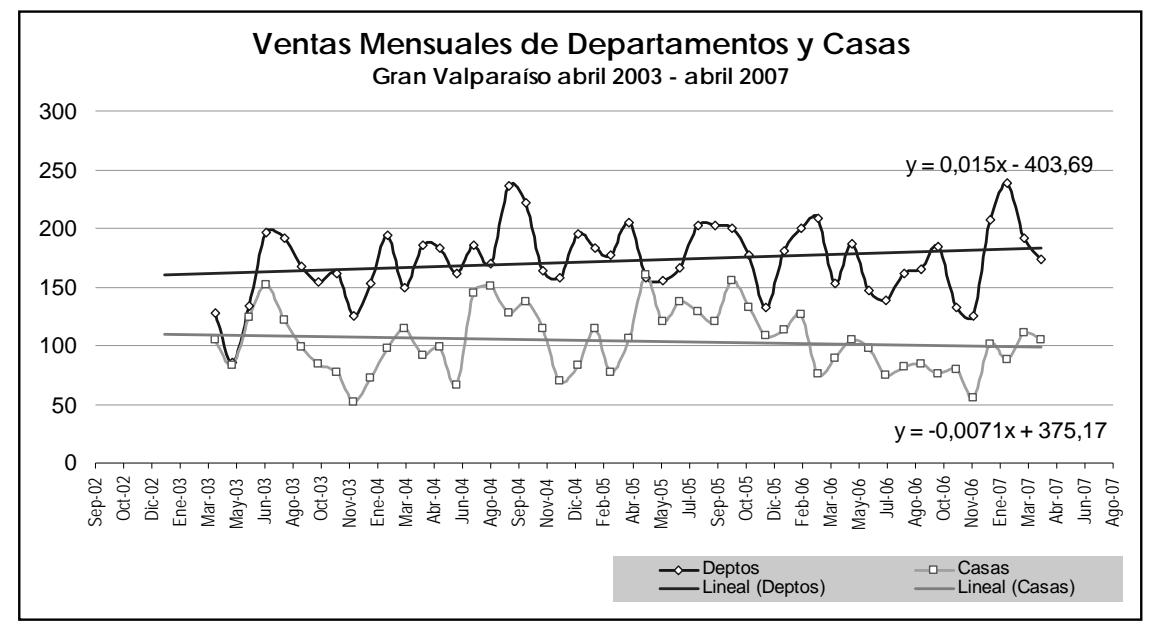


Según la figura, las ventas de casas y departamentos muestran un comportamiento regular mensual, siendo los años 2004 y 2005, los de mayor volumen de venta. La venta anual de unidades habitacionales totales en los últimos 4 años, ha variado entre las 3000 y 3600 unidades, siendo el año de mayor venta el 2005, con 3600 unidades totales vendidas. Respecto del comportamiento en unidades vendidas, de departamentos y casas desde abril de 2003 hasta abril de 2007, a partir del año 2005 se marca una clara tendencia al predominio en la venta de departamentos, representando los dos tercios de las ventas inmobiliarias de dicho año. Sin embargo, la tendencia de los mercados de casas y departamentos divergen crecientemente, mientras la tendencia general de las ventas de departamentos muestra un comportamiento levemente creciente a razón promedio de un 1,5\% mensual, la tendencia de ventas de casas es decreciente a razón de un 0,7\% mensual.

Este comportamiento y especialización del mercado inmobiliario del Gran Valparaíso, se muestra en términos porcentuales en la participación de las ventas totales de departamentos y viviendas, en razón 1:3, como predominio creciente del mercado de oferta de departamentos. Si correlacionamos estos datos con la distribución por zonas de la oferta y ventas inmobiliarias, se constata que la oferta de departamentos, se explica principalmente por la demanda de segundas viviendas para descanso o renta, en las zonas de atracción turística. Por el contrario, la demanda habitacional de los
According to the figure apartments and houses sales show a consistent monthly behavior. The greatest sales volume was in 2004 and 2005. The annual housing units sold the last 4 years has been between 3000 and 3600 units, 2005 had the highest number of houses sold (3600). Apartment and houses Units sold behavior tendency between April 2003 and April 2007 had a clear trend to sell more apartments than houses two thirds of the real estates sales that year, although the apartment and housing market tendency increasingly diverges with slight difference between one and the other, apartments increase in an average $1.5 \%$ and houses decrease around $0.7 \%$ monthly.

This behavior and specialization of Gran Valparaiso real estate markets is shown in terms of apartments and houses total sales share percentages 1:3 proportion with an increasing apartment offer market. If a correlation is done between this data and the real estate offer and sales distribution by zones, it confirms that apartment offer can be easily explained by second house demand either as holiday rest or to rent in tourist attraction zones, on the other hand residents housing demand is offered in the peripheric areas: Curauma, Quilpue, Villa Alemana. 
residentes, está siendo enfrentada por las ofertas de viviendas en los sectores periféricos de Curauma, Quilpué y Villa Alemana.

La oferta de viviendas, por tamaño, se concentra principalmente en las de 71 a $90 \mathrm{~m} 2$ de superficie (35\%) y las de 91 a $110 \mathrm{~m} 2$ de superficie (26\%). Cabe notar que aparece con relevancia también un segmento de viviendas de tamaño pequeño, entre los 51 y $70 \mathrm{~m} 2$, que representan un $21 \%$ de la oferta habitacional. Dicho segmento de oferta, se concentra principalmente en Curauma y Villa Alemana, en cambio la oferta de viviendas en el tramo de 71 a $90 \mathrm{~m} 2$, se concentra principalmente en Quilpué y Curauma. Las viviendas de mayor tamaño se ofertan en Reñaca-Con Con, y el sector que muestra una oferta más amplia en tamaños es Curauma, que abarca viviendas desde los 51 a los $140 \mathrm{~m} 2$ de superficie.

En el caso de los Departamentos, la oferta se distribuye en una gama más amplia de superficies en las mismas proporciones que las viviendas para los tramos entre 51 y $140 \mathrm{~m} 2$, sin embargo, aparece un segmento de superficies menores que $51 \mathrm{~m} 2$, con un porcentaje de incidencia no despreciable (18\%). Esta oferta de departamentos pequeños, se concentra principalmente en el Plan de Viña, Valparaíso (Plan y Cerros), Borde Costero y Reñaca-Con Con. También se puede correlacionar con las características de las zonas en las cuales se emplaza dicha oferta, es decir para segundas viviendas y absorber la demanda de los sectores turísticos y universitarios. Esta última
The housing offer by size, mainly concentrates in 71 and $90 \mathrm{~m} 2$ surface (35\%) and 91 to $110 \mathrm{~m} 2$ surface (26\%). It is also important to mention that a part of the small size housing segment between 51 and $70 \mathrm{~m} 2$ that represent $21 \%$ of the housing offer. This segment mainly concentrates in Curauma and Villa Alemana on the other hand the size 715090 m2 housing offer is mainly in Quilpue and Curauma. The bigger houses are in ReñacaCon Con and the area with the wider range is Curauma with 51 to $130 \mathrm{~m} 2$ housing offer surface spectrum.

Apartments offer distributes in a greater range of surfaces in the same proportion that houses in the range of 51 to $140 \mathrm{~m} 2$, though it also has segments with smaller surfaces than $51 \mathrm{~m} 2$ (18\%) of the market. This small apartment's offer concentrates mainly in Viña Plan, Valparaiso Plan and Hills, Costal Border and Reñaca-Con Con. It also correlates with the zones' characteristics where these apartments are offer, in other words second houses and tourist and university students' demand. This last demand mention explains small apartments offer in Valparaiso.

The above mention makes sense and confirms the hypothesis that decentralized university (new 
centralidad universitaria, explica la incidencia de estos departamentos pequeños en la oferta de Valparaíso.

Esta situación es consecuente y confirma la hipótesis de que la residencia universitaria descentralizada hacia el Gran Valparaíso, sigue el patrón de la oferta inmobiliaria de segundas viviendas, al menos en el caso de Viña del Mar; en el caso de Valparaíso, la tendencia se confirma hacia viviendas nuevas en densidad en el Plan y en forma emergente en Valparaíso Alto.

\section{LOCALIZACIÓN DE LOS ALUMNOS DE LA USM}

Para cartografiar los patrones de localización de los estudiantes de la USM, se accedió a las bases de datos de los alumnos de la Universidad, con su domicilio y tipo de ayuda aplicada a cada uno de ellos (beca de alimentación, crédito fiscal, etc.)

Del universo de 7.800 alumnos se tomó una muestra para dicha labor. La muestra se calculó a partir de la fórmula:

$$
n=\frac{N \times Z_{a}^{2} \times p \times q}{d^{2} \times(N-1)+Z_{a}^{2} \times p \times q}
$$

Donde:

$\mathrm{N}=$ Tamaño de la población

Z=Nivel de Confianza

$\mathrm{p}=$ Probabilidad de éxito, o proporción esperada (estudiante de la USM)

$\mathrm{q}=$ Probabilidad de fracaso housing solutions) towards Gran Valparaiso follows the pattern of second house real estate offer, at least in Viña del Mar, in Valparaiso's case tendency confirms that new housing in density in the plan and emerging in Valparaiso Alto.

\section{USM STUDENTS' LOCATION}

It was access to the university students' data base to map the USM students' location patterns, taking their addresses and type of scholarship or welfare they get if any is received (financial aid, food, etc).

A sample was taken from the universe of 7.800 university students. The sample was calculated using the formula:

$$
n=\frac{N \times Z_{a}^{2} \times p \times q}{d^{2} \times(N-1)+Z_{a}^{2} \times p \times q}
$$

Where:

$N=$ Population size.

$Z=$ Trust level.

$p=$ Success probability or expected proportion (USM student) $q=$ Failure probability. 
d=Precisión (error máximo admisible en términos de proporción)

Sustituyendo:

$$
n=\frac{7800 \times 1,96^{2} \times 0,05 \times 0,95}{0,03^{2} \times(7800-1)+1,96^{2} \times 0,05 \times 0,95}
$$

Al 90\% de confianza, la muestra resulta ser significativa en un tamaño de 366 casos. Estimado el tamaño de la muestra, se procedió a localizar los alumnos con georreferenciación para poder aplicar en el SIG, los análisis que relacionan, los patrones de localización residencial y los patrones de desarrollo de la oferta urbana de movilidad y residencia en el Gran Valparaíso. Se ubicaron en el territorio además las Residenciales Universitarias para comparar dicho patrón de localización con la de los alumnos según GSE.

La figura de abajo muestra el cruce de información y corrobora la correlación existente entre la oferta de residencias universitarias tradicionales estilo "hogares universitarios" (piezas en viviendas existentes), y la localización de los alumnos de menores recursos en el entorno inmediato de la Universidad. Se aprecia además cómo los alumnos de mayores recursos tienden a localizarse dentro del área de influencia de la Isocrona de los 30 minutos de viaje, y en las zonas de oferta inmobiliaria de mayores costos y relacionadas con el Plan de Viña, Borde Costero, Agua Santa-Recreo y hacia el Norte, Reñaca-Con Con. $d=$ Pressure (maximum error accepted in terms of proportion)

Applying the formula:

$$
n=\frac{7800 \times 1,96^{2} \times 0,05 \times 0,95}{0,03^{2} \times(7800-1)+1,96^{2} \times 0,05 \times 0,95}
$$

To $90 \%$ trust, the simple turns out to be significant 366 cases. Once the estimated sample number was chosen, the students were contacted with geo-reference to be able to apply SIG, the analysis that correlate the residential location patterns and mobility urban offer development and resident patterns in Gran Valparaiso. The university students' guest houses were located in the territory to compare those location patterns with the students according to GSE.

The figure below shows the crossed information and confirms the existent correlation between the university students traditional residential offer such as "university students home" (rooms in houses) and low income students location within the immediate university surroundings. It is observed that students with higher income tend to locate within the isochronal curve of 30 minutes influence travel and the most expensive real estate offer related to Viña Plan, Costal Border, Agua Santa-Recreo and towards the North, Reñaca-Con Con. 
Este tipo de alumnos tiende a agruparse para el arrendamiento de departamentos que en el verano constituyen oferta residencial para el turismo de borde costero. Si se observan las figuras de abajo, los alumnos con Crédito Fiscal tienen un patrón de localización espacial más disperso, sin dependencia clara de la cercanía a la Universidad, ni segregados por nivel socioeconómico del lugar de residencia.

Mientras los alumnos que acceden a Becas de Alimentación, buscan patrones de localización cercanos a la Universidad, los alumnos beneficiarios de Crédito Fiscal, muestran un patrón más disperso y siguiendo las tendencias de oferta de departamentos de la gestión inmobiliaria de Viña del Mar y Borde Costero. La mayor dependencia de los alumnos con Becas de alimentación se explica por la necesidad de ocupar día a día dicho beneficio y tiene que ver con la agenda diaria del estudiante, no así el crédito fiscal que tiene que ver con el costo de matrículas, el cual al dotarse al alumno, aumenta sus posibilidades de pagar por mejores localizaciones de residencia. El estudio hasta esta etapa, muestra la importancia de las características del medio urbano en el cual se desarrollan los alumnos de las universidades. Sus patrones de movilidad en ciudades universitarias como el Gran Valparaíso, no son de poca importancia, tanto en tamaño de los viajes como en el uso de recursos y servicios públicos por parte de los alumnos. Lo que inicialmente era una ventaja comparativa para las universidades, localizarse en el centro urbano, poco a poco se transforma en
This type of student tends to rent apartments that in summer are part of the costal border tourist residential offer. If the figures below are observed the students with financial aid have a more disperse spatial location, not with a clear dependency to be close to the university nor segregated by socioeconomic level of the residential location.

While students access to food scholarships (university welfare for low income students, giving them meals within the universities facilities), they look for locations near the university, the students with financial aid show disperse location patterns following the apartment offer tendency within Viña del Mar and Costal border real estate offer. The greater dependency of students with food scholarship is explained because they need to get the benefit from the scholarship in daily basis and it has to do with their daily activity on the other hand financial aid students benefit has to do with fees and enrolment fees which allows the student to pay better residential location. The study so far has shown the importance of the urban environment where the students live. Students' mobility patterns in cities with a population of university students such a Gran Valparaiso are relevant in terms of the travel length as the public services and resources usage by the university students. The university location in the central part of town that used to be a comparative advantage gradually is reverting 
FIGURA 13. DISTRIBUCIÓN DE LA MUESTRA DEESTUDIANTES DE LA USM, SEGÚN ESTRATIFICACIÓN GSEABC1. INCLUYE EN ROJO LOS PUNTOS DE LOCALIZACIÓN DE LAS RESIDENCIALES UNIVERSITARIAS EN EL ENTORNO URBANO

FIGURE 13. USM STUDENTS' SAMPLE DISTRIBUTION, ACCORDING TO GSE ABC1 STRATIFICATION. INCLUDES IN RED DOTS THE UNIVERSITY RESIDENCE LOCATION IN THE URBAN

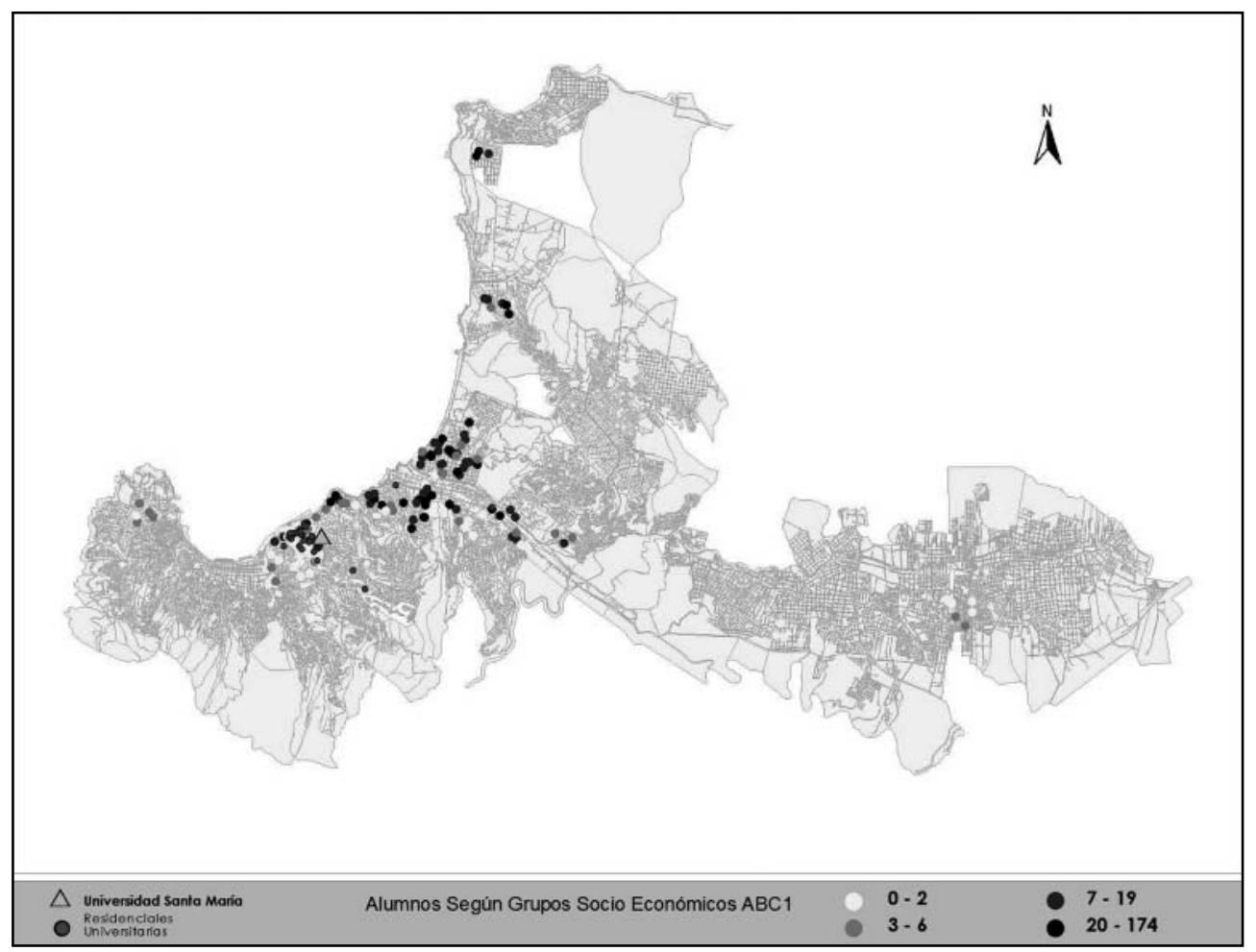


FIGURA 14. ALUMNOS CON BECAS DE ALIMENTACIÓN, ÁREA DE INFLUENCIA DE ISOCRONA DE 30 MINUTOS, Y GRUPOS SOCIOECONÓMICOS ABC1 POR MANZANAS

FIGURE 14.FOOD SCHOLARSHIPS STUDENTS, ISOCRONA INFLUENCE AREA OF 30 MINUTES, AND SOCIO-ECONOMIC GROUPS ABC1 PER BLOCK

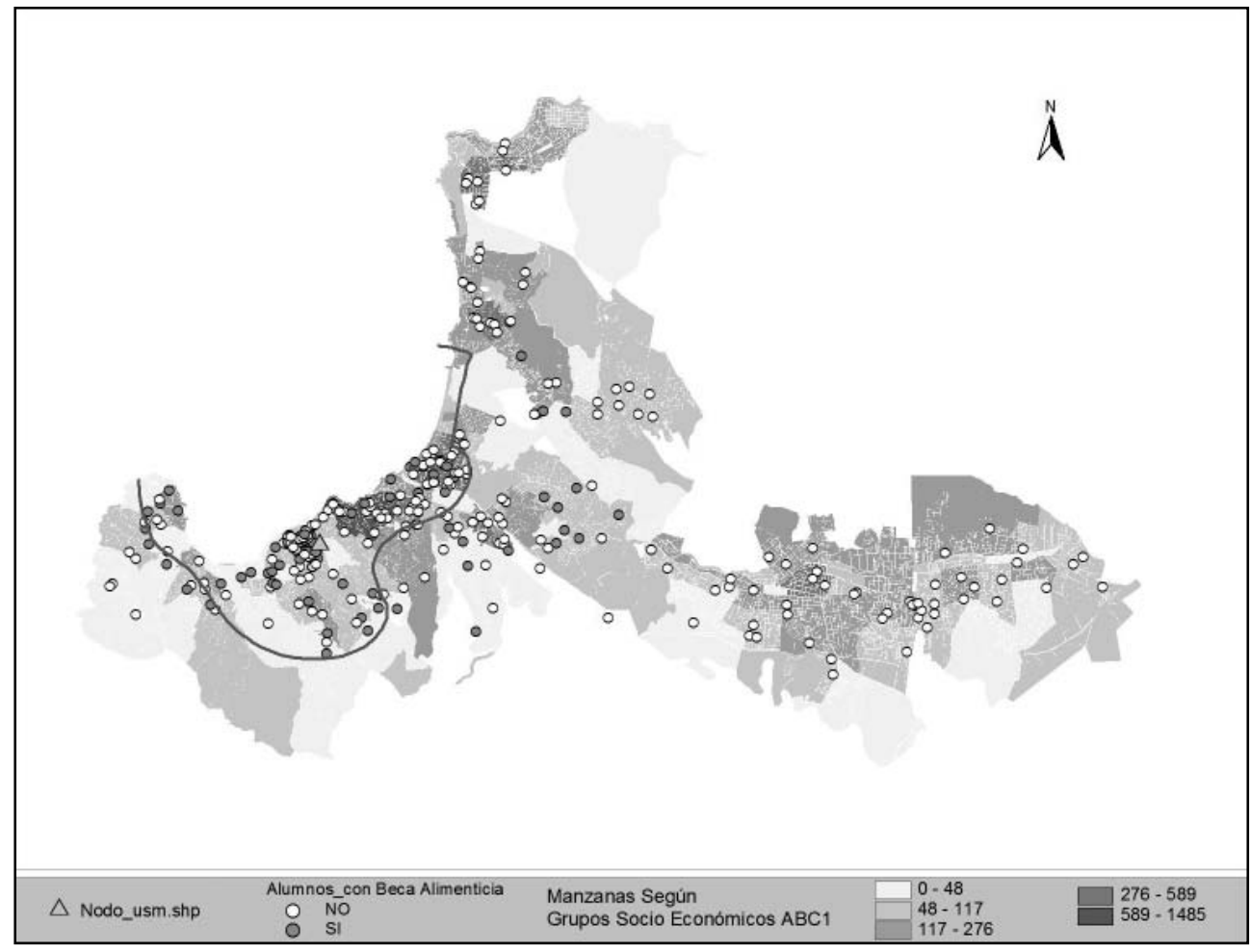


FIGURA 15. ALUMNOS CON CRÉdITO FISCAL, SEGÚN LOCALIZACIÓN EN ZONAS CON GSE ABC1, Y ÁREA DE INFLUENCIA DE ISOCRONA DE 30 MINUTOS DE VIAJE A LA UNIVERSIDAD.

FIGURE 15. FINANCIAL AID STUDENTS, ACCORDING TO LOCATION ZONES GSE ABC1, AND ISOCRONA INFLUENCE AREA WITHIN MINUTES TRAVEL FROM THE UNIVERSITY.

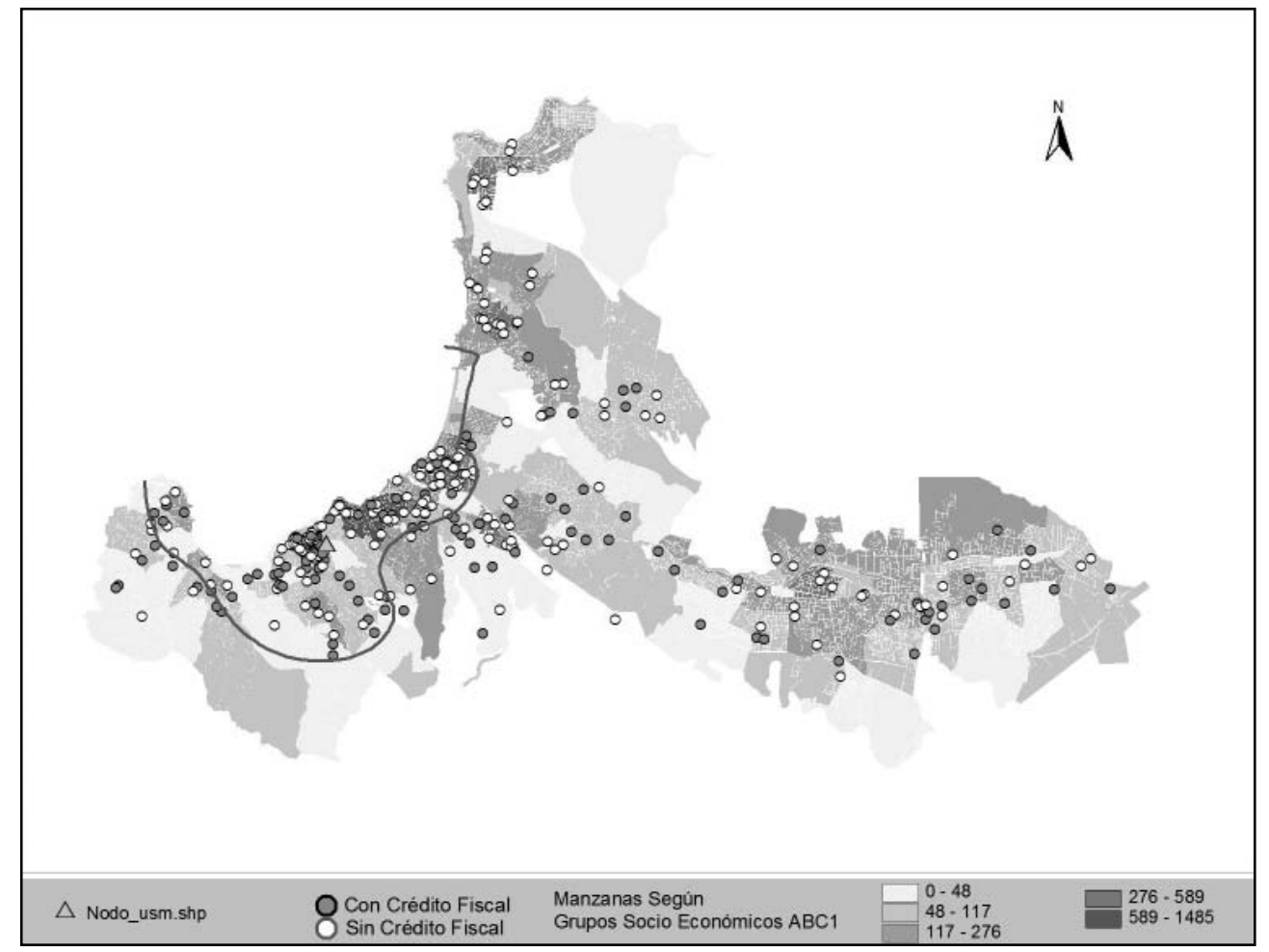


un fenómeno que revierte sus beneficios, pues el contexto de centralidad metropolitana, introduce cambios en las relaciones del campus con la ciudad, tanto en los usos del suelo, que cambian y tienden a la centralidad de servicios y comercio, que expulsan a la actividad residencial en ellos. En este caso lo importante es constatar que el crecimiento de las ciudades impone costos sociales por aumento de tamaño y tiempos de viajes de un lado a otro a todos sus habitantes, problema del cual no están exentos los estudiantes, así como los trabajadores seguramente.

Nace como política necesaria, el que la universidad actúe para mejorar las condiciones de los barrios aledaños que albergan a sus alumnos de mayor interés social, cautivos por la necesaria cercanía a las redes de ayuda de la universidad, pero la dinámica urbana de crecimiento y valorización económica de los terrenos centrales de mayor accesibilidad, plantean procesos de invasión-sucesión que terminarán por transformar los barrios aledaños de las universidades, hacia actividades centrales que impone la demanda metropolitana, antes que las políticas internas de las universidades para con sus alumnos. Unas de las consecuencias de la presente investigación es poner atención a dichas dinámicas de cambio en los entornos universitarios y los denominados "barrios universitarios", tendientes a establecer relaciones más efectivas entre los campus y su entorno urbano de emplazamiento a partir de la experiencia de la movilidad que tienen sus alumnos. its benefits as the metropolitan centrality context introduces changes in relation to the campus with the city; related to land use that changes and tends to centralize services and commerce and moves out residential land use. In this case is important to realize that cities' growth implies social cost because size increase and travel times from one place to another for its inhabitants, problem that students have to deal with as workers for sure do.

It is important that the university develops a necessary policy to improve the conditions of the university neighboring areas that holds its students with greater socialneeds, captive to the surrounding areas because of closeness to the university welfare networks, but the urban growth dynamic and increasing land value and economic value by the accessible central territory has portraits the progressive invasion process that will end up transforming the university neighborhood into central activities center that metropolitan growth demands before the university internal policies help its students related to this issue. One of the consequences of this study is to show this change dynamics within the university surroundings and its so called "university neighborhood" that tend to build more effective relationship with the campus and the urban surroundings from the students mobility experience. 


\section{CONCLUSIONES}

Por cada hora de recorrido de hace 10 años, a raíz de la profusa generación de accesibilidad hoy se recorren 34 kilómetros más, claramente más territorio que cubrir; esto genera beneficios de interrelación y desarrollo vitales para el país, pero también trastorna diversos ámbitos del quehacer urbano, sobre todo aquellos que tienen que ver con la movilidad cotidiana de sus habitantes y específicamente con una comunidad móvil como son los estudiantes universitarios de la Universidad Técnica Federico Santa María.

La Universidad desde su etapa fundacional al presente evolucionó desde el claustro como unidad autosuficiente, a la externalización de sus servicios, incorporando la residencia desde el antiguo pensionado al interior de sus edificios a la oferta que la ciudad o área metropolitana ofrece. Con sus 7.800 alumnos, en el Campus Central, de la Avenida España en Valparaíso, aporta con el 11\% de la matrícula universitaria regional y con ello no sólo atrae alumnos desde las ciudades aledañas sino gracias a su prestigio en ingeniería recibe alumnos desde todo el territorio nacional.

Si a nivel físico las infraestructuras se extienden y se logra abarcar más territorio, a nivel de estudio los datos nos permiten asegurar que sobre un 5\% del estudiantado hoy en día está viajando desde distancias superiores a los 50 kilómetros, que en

\section{CONCLUSIONS}

For each travel hour 10 years ago due to today's' profuse accessibility generation 34 kilometers more are traveled, clearly more territory and this has interrelations benefits and vital developments for the country, but it also changes different urban environments, specially those that deal with its inhabitants daily mobility, specifically with a mobile community as Universidad Tecnica Santa Maria university students are.

The university from its start evolved from a cloister like unit, self sufficient to the services externalization incorporating students' residence within the campus buildings to the city or metropolitan housing offer. The main campus has 7,800 students on España Avenue in Valparaiso and has $11 \%$ of the region university students' enrolment and not only brings students from neighboring cities, but its prestige brings students from all over the country.

If the physical infrastructure extends and reaches a greater territory, the study data shows that $5 \%$ of the students travel over 50 kilometers, that in relative terms (travel time) that is around 20 to 25 proximity. Students from Quillota, San Felipe, Los Andes, 
términos relativos (horas de viaje) está entre 20 y 25 minutos de proximidad. Alumnos de Quillota, San Felipe, Los Andes, Quintero, Limache y Calera, entre otros, siguen viviendo en sus casas, lo que hace 10 años atrás era impensable. El aumento de la movilidad regional y comunal, empieza a dibujar un modelo que externaliza crecientemente la residencia de los alumnos no sólo al contexto urbano y metropolitano sino también regional.

La casa central de la Universidad, por su emplazamiento entre la Ciudad de Valparaíso y Viña del Mar, a través de la Avenida España, principal eje articulador metropolitano (Avenida España/Cuarta Etapa/Troncal Sur), marca los patrones de movilidad diaria del conjunto urbano. En la medida que sus alumnos comienzan a desplegar sus residencias en el espacio urbano metropolitano interior, cada vez más alejados de su entorno inmediato debido a que las mejoras en las condiciones de accesibilidad lo permiten. A su vez los alumnos con residencia permanente viajan cada vez más desde las ciudades del interior (250 mil Hbts), donde el perfil de los habitantes es población mayoritariamente de clase media joven; según el estudio las ciudades del interior concentran la vitalidad del sistema al concentrar las clases medias, fundamentalmente el grupo C3.

Unido a los patrones de movilidad desde los corredores urbanos y centralidades de servicios existe cierto patrón de localización de residencia
Quinteros, Limache and Calera among others that still live in their homes, that 10 years ago was impossible. The regional and community mobility increase starts to draw the growing externalized residential students model not only within the urban and metropolitan context but also regional.

The university main campus by its location in central Valparaiso and Viña del Mar as España Avenue is the main metropolitan axis articulator, (España Avenue/Cuarta Etapal Troncal Sur), sets the daily mobility patterns of the urban area. As its students start spreading their residential location in the inland metropolitan urban area, farther from its immediate surroundings as the accessibility conditions allow it. Also, the students with permanent residence travel each day more than before from inland cities (250.000 inhabitants) where most of the inhabitants profile is middle class young population, according to the study the inland cities concentrate the system's vitality as holds its middle class, especially C3 group.

Linked to the mobility patterns of urban corridors and existing services centralities, there is a residential location pattern strongly dependent in university welfare for some of its students. Those students dependent on food and housing 
fuertemente dependiente a la asistencia social que la universidad mantiene con sus alumnos. Aquellos alumnos dependientes de becas de alimentación y residencia se emplazan en las cercanías de la universidad; en un $90 \%$ en el Cerro Placeres y el $10 \%$ restante en el centro de Valparaíso y Viña. Aquellos que tienen ayuda solamente asociada al crédito universitario, su localización es más dispersa hacia todo el espectro metropolitano, más asociado a una oferta urbana de residencias universitarias tradicionales estilo "hogares universitarios" (piezas en viviendas existentes). Finalmente aquellos alumnos de mayores recursos tienden a localizarse dentro del área de influencia de la Isocrona de los 30 minutos de viaje, y en las zonas de oferta inmobiliaria de mayores costos, departamentos que en el verano constituyen oferta residencial para el turismo de borde costero relacionada con el Plan de Viña, Borde Costero, Agua Santa-Recreo y hacia el Norte, Reñaca-Con Con.

Esta situación es consecuente y confirma la hipótesis de que la residencia universitaria descentralizada hacia el Gran Valparaíso, sigue el patrón de la oferta inmobiliaria de segundas viviendas, al menos en el caso de Viña del Mar. En el caso de Valparaíso, la tendencia se confirma hacia viviendas nuevas en densidad en el Plan y en forma emergente en Valparaíso Alto, como es el Cerro Placeres, que tiene condiciones inmejorables con respecto a sitios de altos metrajes cuadrados, pertenecientes a grandes casonas de principios de siglo. welfare that live near the university; 90\% Los Placeres Hill and $10 \%$ in central Valparaiso and Viña. Those who have only financial aid have a more disperse pattern within the whole metropolitan spectrum, linked to traditional university students' residential urban offer such as "University Homes" (rooms in households). Finally, those students of higher income tend to locate with the isochronal curve, 30 minutes influence travel and in the most expensive real estate housing offer. Apartments that in summer are tourist costal border residential offer area related to Plan Viña, Costal Border, Agua SantaRecreo and towards North, Reñaca-Con Con.

This proves the hypothesis that university students' descentralized residential pattern towards Gran Valparaiso follows the real estate second house offer pattern, at least in Viña de Mar's case. Valparaiso's case the tendency proves that new density housing (new housing solutions) in the Plan and emerging in Valparaiso Alto as in Placeres Hill that has the best conditions as they are old houses from the turn of the $20^{\text {th }}$ century which are spacious and very well located.

Even though the university main campus is located within Valparaiso metropolitan center, it is an advantage from the accessibility point of view, with the gradual real estate buildings 
Si bien la localización de la casa central cercana al centro metropolitano de Valparaíso es ventajosa como punto de alta accesibilidad, con el problema creciente de desarrollos inmobiliarios en altura en todos los centros donde se sitúan primordialmente los alumnos de escasos recursos, se transforma en un "entorno cambiante" para la Universidad. Los servicios o residencias de mayor costo van expulsando gradualmente la actividad residencial del centro (como incipientemente se ve en las figuras 4-12), debido a que los terrenos de mayor accesibilidad y centralidad suben sostenidamente su valor, entonces es esperable que la localización residencial de los alumnos cerca de la Universidad sea cada vez más costosa, y sean desplazados a localizaciones más lejanas en distancia y tiempo.

Los datos demuestran que los alumnos de la casa central siguen moviéndose en una isocróna de 30 minutos y muchos de ellos usan modos no motorizados para acceder a la universidad, por tanto su calidad de vida en proximidad sigue dependiendo de una cohesión urbana que aún es posible sustentar, ¿pero por cuánto tiempo?

El aumento sostenido de las matriculas de pregrado, 1,3\% anual, y por consiguiente el apoyo y asistencialismo de las universidades nacionales, hace extensible a las ciudades su mayor carga de impacto, a saber; residencia, alimentación, esparcimiento y salud, que requieren un sistema de transporte para apoyar la "explosión de movilidad", development in every center where the most of the low income students are, transforming it into a "changeable surrounding" for the university. Higher cost services or residence gradually push away the center's residential activity (figure 4-12 shows this new trend), due to the fact the land with better access and centrality have a sustained value rise, so it is predictable that residential areas around campus is going to be more expensive each year, so the students' residential location in that area will gradually disappeared pushing the students to farther distances and longer travel time.

The data shows that some students from the university main campus still move around the isochronal curve of 30 minutes and many of them have their own vehicles to access to the university, so their quality of life in proximity still depends on urban cohesion that still is possible to support, though for how much longer can this cohesion be kept?

The increasing 1.3\% annually rate enrolment of first year college students' therefore national university assistant and support to these students extends to the cities that have greater impact for their residential, food, entertainment, health needs and requires an adequate transport system to support the "mobility explosion", key 
clave de las problemáticas urbanas metropolitanas. Nace así la necesidad de crear políticas universitarias que se anticipen a los cambios. Si bien los datos demuestran que sólo el 5\% de alumnos viven fuera de las comunas del Gran Valparaíso, medidas como buses de acercamiento o becas de movilidad quizás debieran esperar, pero políticas que logren mejorar las condiciones de los barrios aledaños que albergan a sus alumnos de mayor interés social, cautivos por la necesaria cercanía a las redes de ayuda, se hacen primordiales.

Una de las consecuencias de la presente investigación es poner atención a las dinámicas de cambio urbanas miradas desde una comunidad móvil específica como es la universitaria. Las relaciones entre el contexto de oferta urbana metropolitana en la cual se emplaza la universidad con los patrones de movilidad cotidiana de los alumnos según estrato socioeconómico, logran configurar un territorio claramente distinguible y caracterizable. to the metropolitan problems. It is then needed university policies that anticipate the changes, although the data shows that only 5\% of the students live out side Gran Valparaiso, measures as proximity buses or mobility financial aid maybe can wait, but policies that address improving the neighboring areas that holds the university low income students, captive by the university welfare network system that these students need to survive are essential.

One of main consequences of this study is to pay attention to urban changes dynamic from the mobile community perspective from an specific group such as the university students. The relationships between the urban metropolitan context offers where the university is located with the university students daily mobility patterns according to the socio-economic stratum that allows to clearly characterizing and configurate a territory. 


\section{BIBLIOGRAFIA/BIBLIOGRAPHY}

ASCHER, Francois. "Multi-Mobility, Multispeed Cities: a challenge for architects, town planners and politicians" The explosion of the City, Morphologies, Observations and Motions, Font A. Ed., Llop C., Bernadó J. \& Colegio de Arquitectos de Cataluña, 2004. págs. 352-363.

ASCHER, Francois. Los Nuevos Principios del Urbanismo; Alianza editorial, Madrid 2004. Primera edición, Les Nouveaux principes de Lurbanisme edición de Laube, 2001.

ALLEN, Stan. "Infrastructural Urbanism". "Points and Lines: Diagrams and Projects for the City" Princeton Architectural Press, 1999.

ÁLVAREZ, Luis y otro. "Estructuración Territorial de la Macro Región Central de Chile". Revista Geográfica de Valparaíso n 28, 1997.

ÁLVAREZ, Luis y otros. "Análisis socioespacial de la pobreza en la región de Valparaíso", Revista Geográfica de Valparaíso n 28, 1996.

ÁLVAREZ, Luis y otro. "Los asentamientos de población en la cuenca del río Aconcagua, V Región. Conflictos de uso de suelo urbano-rural". Revista Geográfica de Valparaíso no 24-25, 1994.

BODINI, Hugo."Geografía Urbana”. Colección Geografía de Chile. Instituto Geográfico Militar. Santiago de Chile, 1987.
CARAVACA, Inmaculada. "Los nuevos espacios ganadores y emergentes", en EURE Revista de Estudios Regionales, N²7, Santiago, 2000.

CASTELLS, Manuel. "Reestructuración económica, revolución tecnológica y nueva configuración del territorio", en VV.AA. Metrópolis, territorio y crisis. Madrid, Asamblea de Madrid. Revista Alfoz. 1985, pp. 37-62.

CASTELLS, Manuel. «El auge de la ciudad dual: teoría social y tendencias sociales», Alfoz, núm. 90, 1991, pp. 89-102.

CASTELLS, Manuel. La ciudad informacional. Madrid. Alianza. "La era de la Información", 3 tomos. Madrid. Alianza. 1996.

DAHER, Antonio. "Macroeconomía de las externalidades urbanas", Revista Interamericana de Planificación, Vol. XXIII, Nº 89, 1990.

DE MATTOS, Carlos Antonio: Crecimiento y Concentración espacial en América Latina: Algunas Consecuencias. Programa de Capacitación ILPESCEPAL, Naciones Unidas, Documento CPRI) B/ 22. 1978.

DUPUY, Gabriel. El Urbanismo de las redes, Teorías y métodos. Oikos Tau, Colegio de Ingenieros de caminos, Canales y Puertos. España, 1998. 
ETXEZARRETA, M. «Globalización y regionalización. ¿La irrelevancia de las Periferias?" Ponencia presentada al Congreso Internacional. A Periferia Europea Ante o Novo Século. Santiago de Compostela, 1993.

ECHEÑIQUE, Marcial y SAN, Andrew (editores). "las Ciudades durante el Nuevo Milenio". Spon Press, 2001.

GAUSA, Manuel. "Territorio y mutabilidad, Nuevas mapificaciones", en You are here, Laura Kurgan y Xavier Costa, Barcelona, MACBA, 1995.

GALILEA, 0. Sergio. "Las Estrategias Prevalecientes de Regionalización y su incidencia en el ordenamiento territorial en Chile". Documento inédito, 1990.

GARREAU, Joel. "Edge City, Life on the new Frontier". New York: Doubleday ed., 1991.

GRAHAM, Stephen y MARVIN, Simon. "Splintering Urbanism, Networked infrastructures, technological mobilities and the urban condition" 2001 by Routledge, London, England.

GUERRA, Velásquez Pedro. "El Estado del SistemaUrbano Chileno y su Imagen de Futuro (1960-1982)" Revista Geográfica de Valparaíso N' 20-21, enero 1989-diciembre 1990. Ediciones Universitarias de Valparaíso, Universidad Católica de Valparaíso, Chile, 1990.

HALL Peter. "Ciudades del mañana". Historia del urbanismo en el siglo XX. Ediciones del Serbal. España, 2000.
HARVEY, David. The urbanisation of capital: studies in the history and theory of capitalist urbanisation. Baltimore, Johns Hopkins University Press, 1985.

HARVEY, David. The Conditions of Posmodernity: an Enquiry into the Origins of Cultural Change. Oxford. Blakwell, 1989.

HARVEY, David. Justice, Nature and the Geography of Difference. Oxford. Blakwell, 1996.

HIERNAUX, D. y LINDON, A. "¿En qué sentido las desigualdades regionales? EURE. vol. XXII, Nº 68 . 1997, pp. 29-43.

INDOVINA, Francesco dir. La cittá di fine millennio. Milán, Franco Angeli, 1990.

INDOVINA, Francesco. Algunes consideracions sobre la "ciutat difusa" en Documents de Análisi Geográfica. Pag. 21 -32, Universitat Autónoma de Barcelona, Server de Publicacions. Barcelona, 1998.

LEFEBVRE, Henri. "De lo Rural a lo Urbano" Ediciones Península, Barcelona, 1971.

LEBORGNE, Daniele y LIPIETZ, Alain. "Nuevas tecnologías, nuevas formas de regulación: algunas consecuencias espaciales". Serie ILPES 151, Naciones Unidas, 1989.

MARTÍNEZ Miguelez, Miguel. (1997) "El paradigma emergente, Hacia una nueva teoría de la racionalidad científica", México, Editorial Trillas.

MIRALLES-GUASCH, C. Ciudad y Transporte, el binomio imperfecto, editado por Ariel Geografía, Barcelona, 2002. 
MIRALLES-GUASCH \& Cebollada A. Movilidad y Transporte. Opciones políticas para la Ciudad, editado por Fundación Alternativas, 2003.

NEGRETE S. Jorge, GUERRA V. Pedro. "Desarrollo y Gestión en el Área Metropolitana de Valparaíso". Revista Geográfica No 100, julio-diciembre 1984. Instituto Panamericano de Geografía e Historia.

SECTRA. Construcción de planes Estratégicos de Desarrollo del STU del Gran Valparaíso, I Etapa, 2003.

SECTRA. Censo de flujos de tráfico - V etapa, informe ejecutivo final Quinta Región, 2006.

WHITELEGG, J. "Critical mass transport, enviroment and society, in the twenty first century, Pluto, Londres; citado en Ciudad y Transporte, el binomio imperfecto, editado por Ariel Geografía, Barcelona, 1997. 